\title{
Studies on Phosphatidylserine by Tandem Quadrupole and Multiple Stage Quadrupole Ion-Trap Mass Spectrometry with Electrospray Ionization: Structural Characterization and the Fragmentation Processes
}

\author{
Fong-Fu Hsu and John Turk \\ Mass Spectrometry Resource, Division of Endocrinology, Diabetes, Metabolism, and Lipid Research, \\ Department of Internal Medicine, Washington University School of Medicine, St. Louis, Missouri, USA
}

Low-energy CAD product-ion spectra of various molecular species of phosphatidylserine (PS) in the forms of $[\mathrm{M}-\mathrm{H}]^{-}$and $[\mathrm{M}-2 \mathrm{H}+\mathrm{Alk}]^{-}$in the negative-ion mode, as well as in the forms of $[\mathrm{M}+\mathrm{H}]^{+},[\mathrm{M}+\mathrm{Alk}]^{+},[\mathrm{M}-\mathrm{H}+2 \mathrm{Alk}]^{+}$, and $[\mathrm{M}-2 \mathrm{H}+3 \mathrm{Alk}]^{+}$(where Alk $=\mathrm{Li}$, $\mathrm{Na}$ ) in the positive-ion mode contain rich fragment ions that are applicable for structural determination. Following $\mathrm{CAD}$, the $[\mathrm{M}-\mathrm{H}]^{-}$ion of PS undergoes dissociation to eliminate the serine moiety (loss of $\mathrm{C}_{3} \mathrm{H}_{5} \mathrm{NO}_{2}$ ) to give a $[\mathrm{M}-\mathrm{H}-87]^{-}$ion, which equals to the $[\mathrm{M}-\mathrm{H}]^{-}$ ion of a phoshatidic acid (PA) and give rise to a $\mathrm{MS}^{3}$-spectrum that is identical to the $\mathrm{MS}^{2}$-spectrum of PA. The major fragmentation process for the $[\mathrm{M}-2 \mathrm{H}+\mathrm{Alk}]^{-}$ion of PS arises from primary loss of 87 to give rise to a [M $-2 \mathrm{H}+\mathrm{Alk}-87]^{-}$ion, followed by loss of fatty acid substituents as acids $\left(\mathrm{R}_{\mathrm{x}} \mathrm{CO}_{2} \mathrm{H}, \mathrm{x}=1,2\right)$ or as alkali salts (e.g., $\left.\mathrm{R}_{\mathrm{x}} \mathrm{CO}_{2} \mathrm{Li}, \mathrm{x}=1,2\right)$. These fragmentations result in a greater abundance of $\left[\mathrm{M}-2 \mathrm{H}+\mathrm{Alk}-87-\mathrm{R}_{2} \mathrm{CO}_{2} \mathrm{H}\right]^{-}$than $\left[\mathrm{M}-2 \mathrm{H}+\text { Alk }-87-\mathrm{R}_{1} \mathrm{CO}_{2} \mathrm{H}\right]^{-}$and a greater abundance of $[\mathrm{M}-2 \mathrm{H}+\mathrm{Alk}-87-$ $\left.\mathrm{R}_{2} \mathrm{CO}_{2} \mathrm{Li}\right]^{-}$than $\left[\mathrm{M}-2 \mathrm{H}+\mathrm{Alk}-87-\mathrm{R}_{1} \mathrm{CO}_{2} \mathrm{Li}\right]^{-}$; while further dissociation of the $[\mathrm{M}-2 \mathrm{H}$ + Alk $\left.-87-\mathrm{R}_{2(\text { or } 1)} \mathrm{CO}_{2} \mathrm{Li}\right]^{-}$ions gives a preferential formation of the carboxylate anion at sn-1 $\left(\mathrm{R}_{1} \mathrm{CO}_{2}^{-}\right)$over that at $s n-2\left(\mathrm{R}_{2} \mathrm{CO}_{2}^{-}\right)$. Other major fragmentation process arises from differential loss of the fatty acid substituents as ketenes (loss of $\mathrm{R}_{\mathrm{x}}{ }^{\prime} \mathrm{CH}=\mathrm{CO}, \mathrm{x}=1,2$ ). This results in a more prominent $\left[\mathrm{M}-2 \mathrm{H}+\mathrm{Alk}-\mathrm{R}_{2}{ }^{\prime} \mathrm{CH}=\mathrm{CO}\right]^{-}$ion than $[\mathrm{M}-2 \mathrm{H}+\mathrm{Alk}-$ $\left.\mathrm{R}_{1}{ }^{\prime} \mathrm{CH}=\mathrm{CO}\right]^{-}$ion. Ions informative for structural characterization of PS are of low abundance in the $\mathrm{MS}^{2}$-spectra of both the $[\mathrm{M}+\mathrm{H}]^{+}$and the $\left[\mathrm{M}+\mathrm{Alk}^{+}\right.$ions, but are abundant in the $\mathrm{MS}^{3}$-spectra. The $\mathrm{MS}^{2}$-spectrum of the $[\mathrm{M}+\mathrm{Alk}]^{+}$ion contains a unique ion corresponding to internal loss of a phosphate group probably via the fragmentation processes involving rearrangement steps. The $[\mathrm{M}-\mathrm{H}+2 \mathrm{Alk}]^{+}$ion of PS yields a major $[\mathrm{M}-\mathrm{H}+2 \mathrm{Alk}-87]^{+}$ ion, which is equivalent to an alkali adduct ion of a monoalkali salt of PA and gives rise to a greater abundance of $\left[\mathrm{M}-\mathrm{H}+2 \mathrm{Alk}-87-\mathrm{R}_{1} \mathrm{CO}_{2} \mathrm{H}\right]^{+}$than $[\mathrm{M}-\mathrm{H}+2 \mathrm{Alk}-87-$ $\left.\mathrm{R}_{2} \mathrm{CO}_{2} \mathrm{H}\right]^{+}$. Similarly, the $[\mathrm{M}-2 \mathrm{H}+3 \mathrm{Alk}]^{+}$ion of PS also yields a prominent $[\mathrm{M}-2 \mathrm{H}+3 \mathrm{Alk}$ $-87]^{+}$ion, which undergoes consecutive dissociation processes that involve differential losses of the two fatty acyl substituents. Because all of the above tandem mass spectra contain several sets of ion pairs involving differential losses of the fatty acid substituents as ketenes or as free fatty acids, the identities of the fatty acyl substituents and their positions on the glycerol backbone can be easily assigned by the drastic differences in the abundances of the ions in each pair. (J Am Soc Mass Spectrom 2005, 16, 1510-1522) (c) 2005 American Society for Mass Spectrometry

$\mathrm{P}$ hosphatidylserine (PS, 1,2-diacyl-sn-glycero-3phosphorylserine) occurs quite widely in nature but usually in low concentrations (3-10\%) of the total phospholipids. The compound was first isolated

Published online July 15, 2005

Address reprint requests to Dr. F.-F. Hsu, Department of Internal Medicine, Washington University School of Medicine, 660 S. Euclid, Box 8127, St. Louis, MO 63110, USA. E-mail: fhsu@im.wustl.edu by Folch from brain [1] and the exact structure was later established by Baer and Maurukas [2,3].

In yeast and prokaryotes, PS is made by a PS synthase that uses CDP-diacylglycerol and serine [4]. However, in mammals, PS is generated by a base-exchange reaction in which L-serine substitutes the choline and ethanolamine moieties of phosphatidylcholine and phosphatidylethanolamine, respectively, with the participation of PS synthase 1 and PS synthase 2, respectively, to yield PS and choline or ethanolamine [5]. The major route for PE synthesis in 
cells is from the mitochondrial decarboxylation of PS using decarboxylase [6].

In addition to its presumed contribution to membrane structure, PS has been evidenced to engage in a number of key cellular processes. For example, PS is an activator of several enzymes such as protein kinase $C$ [7], $\mathrm{Na}^{+} / \mathrm{K}^{+}$ATPase [8], and neutral sphingomyelinase $[9,10]$. The externalization of PS on the cell surface is thought to be a critical signal for platelet activation during the blood clotting cascade [11], for skeletal muscle development [12], and for macrophage recognition of cells undergoing apoptosis [13-18]. Phosphatidylserine receptor is recognized to be essential for removing apoptotic cells during mammalian development of lung and brain [19].

Mass spectrometric methods with FAB ionization toward to the structural characterization of PS in the [M $+\mathrm{H}]^{+}$form have been previously performed by tandem sector [20] and tandem quadrupole mass spectrometers [21] following collisionally activated dissociation (CAD). More structural information can be obtained from low-energy CAD of the $[\mathrm{M}-\mathrm{H}]^{-}$species in the negative-ion mode [21]. Although brief studies on the adduct ions in the fashions of $[\mathrm{M}-\mathrm{H}+\mathrm{Co}]^{+}$and of $\left[\mathrm{M}-\mathrm{H}+\mathrm{Ni}^{+}\right.$using ion-trap mass spectrometers have been reported [22], there have been very few detailed studies of the molecular ion species generated by electrospray ionization (ESI) [23]. ${ }^{\circ} \mathrm{Herein},{ }^{\circ} \mathrm{we}^{\circ} \mathrm{de}-$ scribe ESI with tandem quadrupole and with quadrupole ion-trap mass spectrometric methods to characterize PS in the forms of $[\mathrm{M}-\mathrm{H}]^{-}$and $\left[\mathrm{M}-2 \mathrm{H}+\mathrm{Alk}^{-}\right.$ in the negative-ion mode, as well as in the forms of [M $+\mathrm{Alk}^{+},[\mathrm{M}-\mathrm{H}+2 \mathrm{Alk}]^{+}$and $[\mathrm{M}-2 \mathrm{H}+3 \mathrm{Alk}]^{+}(\mathrm{Alk}$ $=\mathrm{Li}, \mathrm{Na}$ ) in the positive-ion mode. The fragmentation processes under low-energy CAD are also proposed.

\section{Materials and Methods}

Phosphatidylserine and phosphatidic acid standards (sodium salt) were purchased from Avanti Polar lipid (Alabaster, AL). All solvents are of research grade and were purchased from Fisher Scientific (Pittsburgh, PA). To convert sodium into lithium salt form, PS (in $\mathrm{Na}^{+}$ form) in chloroform was added to distilled water, sonicated for $2 \mathrm{~min}$. The mixture was centrifuged for 5 $\mathrm{min}$ at $3000 \mathrm{rpm}$. Lower phase containing PS was collected, diluted with methanol, and $\mathrm{LiOH}(0.1$ $\mathrm{umol} / \mathrm{uL}$ in methanol) was added. The final solution contains $1 \mathrm{nmol} / \mathrm{uL} \mathrm{LiOH}$ and 10-100 pmol/uL PS in methanol/chloroform (vol/vol, 2/1). Deuterium labeled 16:0/18:1-PS were prepared by dissolving $\mathrm{d}_{0}-16$ : 0/18:1-PS standard in 95/5 (vol/vol) $\mathrm{CH}_{3} \mathrm{OD} / \mathrm{CH}_{3} \mathrm{OH}$. When being subjected to ESI, the solution gives the [M $-\mathrm{H}]^{-}$ions at $m / z 760\left(\mathrm{~d}_{0}-16: 0 / 18: 1-\mathrm{PS}\right), 761\left(\mathrm{~d}_{1}-16: 0 /\right.$ 18:1-PS), $762\left(\mathrm{~d}_{2}-16: 0 / 18: 1-\mathrm{PS}\right)$, and $763\left(\mathrm{~d}_{3}-16: 0 / 18: 1-\right.$ PS) ions in a ratio of $0.25 / 0.8 / 1 / 0.35$.

\section{Mass Spectrometry}

Low-energy CAD tandem mass spectrometry experiments were conducted on a Finnigan (San Jose, CA) TSQ 7000 mass spectrometer equipped with ICIS data system or on a LCQ DECA ion-trap mass spectrometer with X-calibur operation system. Solutions containing PS were continuously infused into the ESI source with a syringe pump at a flow rate of $1 \mathrm{uL} / \mathrm{min}$. The skimmer was at ground potential and the electrospray needle was set at $4.5 \mathrm{kV}$. The temperature of the heated capillary was $260^{\circ} \mathrm{C}$. For product-ion spectra obtained with a triple stage quadrupole (TSQ) instrument, the precursor ions were selected in the first quadrupole (Q1), collided with $\operatorname{Ar}(2.3$ mTorr) in the rf-only second quadrupole (Q2) using a collision energy of $30-35 \mathrm{eV}$, and analyzed in the third quadrupole (Q3). Both Q1 and Q3 were tuned to unit mass resolution and scanned at a rate of $3 \mathrm{~s} / \mathrm{scan}$. The mass spectra were accumulated in the profile mode, typically for $5 \mathrm{~min}$ for a tandem mass spectrum. For CAD tandem mass spectra obtained with a quadrupole ion-trap mass spectrometer (ITMS), the automatic gain control of the ion trap was set to $5 \times 10^{7}$, with a maximum injection time of $400 \mathrm{~ms}$. Helium was used as the buffer and collision gas at a pressure of $1 \times$ $10^{-3}$ mbar. The mass resolution was $0.6 \mathrm{Da}$ at half peak height. To maximize the sensitivity and to obtain a more even distribution of the fragment ions for the $\mathrm{MS}^{\mathrm{n}}$ spectra $(n \geq 2)$, a relative collision energy varied from 30 to $38 \%$ was used with an activation time at $100 \mathrm{~ms}$, and the activation $\mathrm{q}$ value at 0.25 .

\section{Results and Discussion}

When being subjected to ESI in the negative-ion mode, phosphatidylserine yields a prominent $[\mathrm{M}-\mathrm{H}]^{-}$ion. In the presence of alkali ion, however, molecular species in the form of $[\mathrm{M}-2 \mathrm{H}+\mathrm{Alk}]^{-}(\mathrm{Alk}=\mathrm{Li}, \mathrm{Na})$ can also be observed, attributable to the fact that PS possesses two anionic charge sites of which one can attach to an $\mathrm{Alk}^{+}$. In the positive-ion mode, PS yields $[\mathrm{M}+\mathrm{H}]^{+}$ion, and adduct ions in the fashions of $[\mathrm{M}+\mathrm{Alk}]^{+},[\mathrm{M}-\mathrm{H}+$ $2 \mathrm{Alk}]^{+}$, and $[\mathrm{M}-2 \mathrm{H}+3 \mathrm{Alk}]^{+}(\mathrm{Alk}=\mathrm{Li}, \mathrm{Na})$ can also be formed, when being ionized in the presence of alkali metal ion. However, the sensitivity in the positive-ion mode is about one order of magnitude less than that observed as the $[\mathrm{M}-\mathrm{H}]^{-}$ion in the negative-ion mode. Structural characterization of the various molecular species of PS by tandem quadrupole and ion-trap mass spectrometry and the fragmentation pathways leading to ion formations are described below.

\section{The $[\mathrm{M}-\mathrm{H}]^{-}$Ions}

PS produces a prominent $[\mathrm{M}-\mathrm{H}]^{-}$ion by ESI along with $[\mathrm{M}-\mathrm{H}-87]^{-}$ion, indicating that PS is labile and readily undergoes in-source fragmentation to expel the serine head group (loss of $\mathrm{C}_{3} \mathrm{H}_{5} \mathrm{NO}_{2}, 87 \mathrm{Da}$ ). This is consistent with the notion that the IT MS ${ }^{2}$-spectrum of 

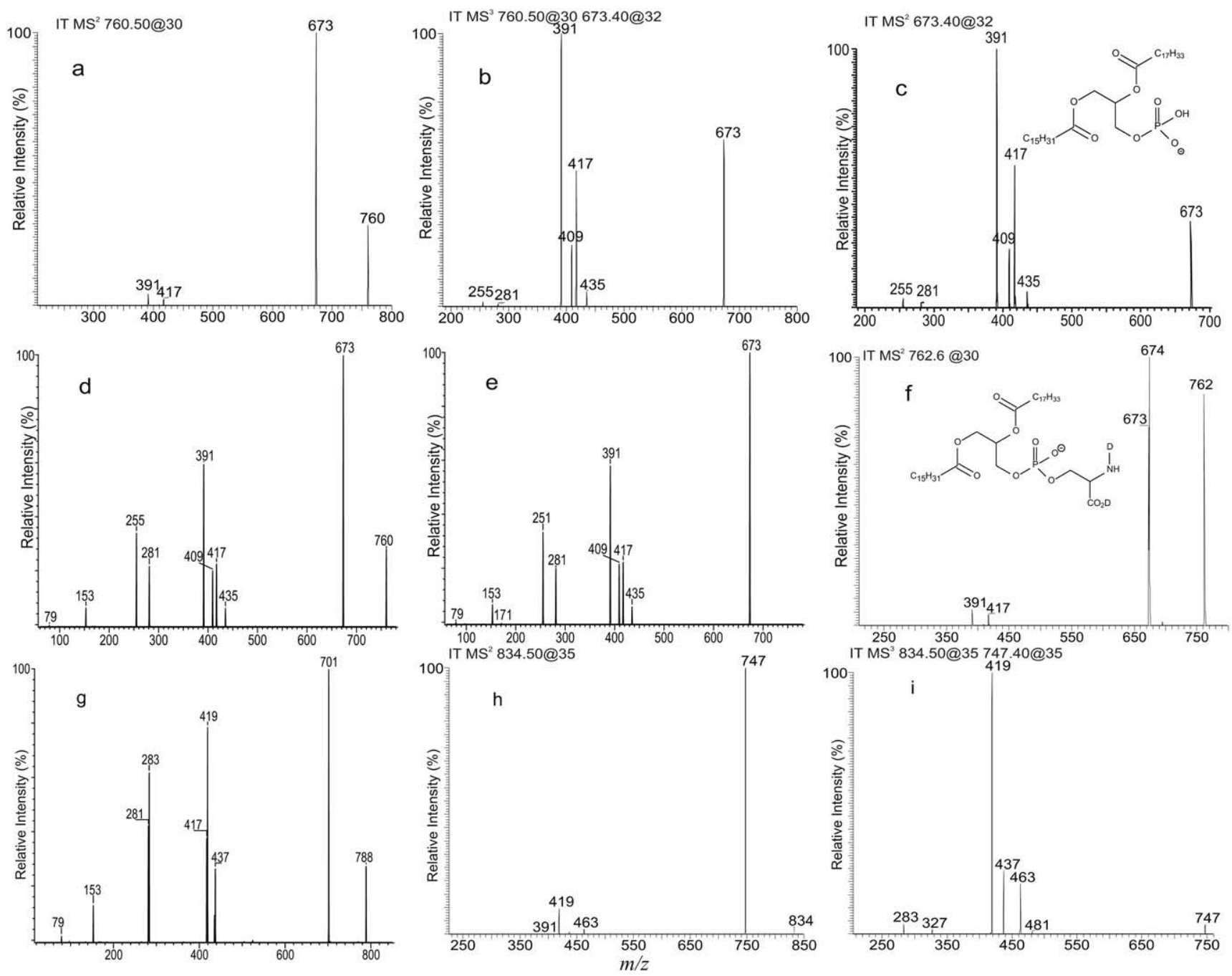

Figure 1. (a) The IT $\mathrm{MS}^{2}$-spectrum of the $\left[\mathrm{M}-\mathrm{H}^{-}\right.$ion of $16: 0 / 18: 1-\mathrm{PS}$ at $\mathrm{m} / \mathrm{z} 760$, (b) its IT $\mathrm{MS}^{3}$-spectrum of the $\mathrm{m} / \mathrm{z} 673$ ion $\left([\mathrm{M}-\mathrm{H}-87]^{-}\right)(760 \rightarrow 673)$, (c) the IT $\mathrm{MS}^{2}$-spectrum of the [M $\mathrm{H}]^{-}$ion of 16:0/18:1-PA at $m / z 673$, (d) the tandem quadrupole product-ion spectrum of the $[\mathrm{M}-\mathrm{H}]^{-}$ ion of 16:0/18:1-PS at $m / z 760$, (e) the source CAD product-ion-spectrum of the $m / z 673$ ion $(760 \rightarrow 673)$, (f) the IT MS' ${ }^{2}$-spectrum of the $[\mathrm{M}-\mathrm{H}]^{-}$ion of $\mathrm{d}_{2}-16: 0 / 18: 1-\mathrm{PS}$ at $m / z 762$, (g) the tandem quadrupole product-ion spectrum of the $[\mathrm{M}-\mathrm{H}]^{-}$ion of 18:0/18:1-PS at $m / z 788$, (h) the IT $\mathrm{MS}^{2}$-spectrum of the $[\mathrm{M}-\mathrm{H}]^{-}$ion of 18:0/22:6-PS at $\mathrm{m} / \mathrm{z} 834$, and (i) its IT MS ${ }^{3}$-spectrum of $\mathrm{m} / \mathrm{z} 747(834 \rightarrow 747)$.

the $[\mathrm{M}-\mathrm{H}]^{-}$ion of 1-palmitoyl-2-oleoyl-3-sn-glycerophosphoserine (16:0/18:1-PS) at $\mathrm{m} / \mathrm{z} 760$ is dominated by $^{\circ}$ the ${ }^{\circ} \mathrm{m} / z$ 673 ${ }^{\circ}$ ion $^{\circ}\left(\left[\mathrm{M}^{\circ}-{ }^{\circ} \mathrm{H}^{\circ}-{ }^{\circ} 87\right]^{-}\right)^{\circ}$ (Figure $\left.{ }^{\circ} 1 \mathrm{a}\right){ }^{\circ}$ which is equivalent to the $[\mathrm{M}-\mathrm{H}]^{-}$ion of 1-palmitoyl-2oleoyl-3-sn-glycero-phosphatidic acid (16:0/18:1-PA) and $^{\circ}$ gives $^{\circ}$ rise $^{\circ}$ to $^{\circ} \mathrm{a}^{\circ} \mathrm{MS}^{3}$-spectrum ${ }^{\circ}\left(760^{\circ} \rightarrow{ }^{\circ} 673\right)^{\circ}$ (Figure 1b) ${ }^{\circ}$ identical ${ }^{\circ}$ to $^{\circ}$ that ${ }^{\circ}$ arising ${ }^{\circ}$ from $^{\circ}$ an $^{\circ}$ authentic ${ }^{\circ} 16: 0 / 18$ : 1-PA ${ }^{\circ}$ standard ${ }^{\circ}$ (Figure $\left.1 \mathrm{c}\right)$. The ${ }^{\circ}$ fragmentation ${ }^{\circ}$ process ${ }^{\circ}$ is also consistent with the findings that the tandem quadrupole product-ion spectrum of the $[\mathrm{M}-\mathrm{H}]^{-}$ion at $\mathrm{m} / \mathrm{z}$

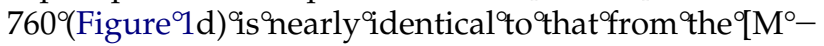
$\mathrm{H}]^{-}$ion of standard 16:0/18:1-PA and that of the $\mathrm{m} / \mathrm{z}$ $673^{\circ}$ ion $^{\circ}\left(760^{\circ} \rightarrow{ }^{\circ} 673\right)^{\circ}\left(\right.$ Figure 1 e) ${ }^{\circ}$ generated by $^{\circ}$ in-source CAD of 16:0/18:1-PS. The ions at $m / z 391\left(\left[\mathrm{M}-\mathrm{H}^{-}-\right.\right.$ $\left.87-\mathrm{R}_{2} \mathrm{CO}_{2} \mathrm{H}\right)$ and $m / z 417\left([\mathrm{M}-\mathrm{H}]^{-}-87-\mathrm{R}_{1} \mathrm{CO}_{2} \mathrm{H}\right)$ arising from the respective loss of the fatty acids at $s n-1$ and at $s n-2$ are, respectively, more abundant than the ions at $m / z 409\left([\mathrm{M}-\mathrm{H}]^{-}-87-\mathrm{R}_{2}{ }_{2} \mathrm{CH}=\mathrm{C}=\mathrm{O}\right)$ and $m / z 435\left([\mathrm{M}-\mathrm{H}]^{-}-87-\mathrm{R}_{1}^{\prime} \mathrm{CH}=\mathrm{C}=\mathrm{O}\right)$, arising from their ${ }^{\circ}$ corresponding ${ }^{\circ}$ ketene $^{\circ}$ losses $^{\circ}\left(\right.$ Figure $\left.^{\circ} 1 \mathrm{a}-\mathrm{Q}\right) .^{\circ}$ These spectrum $^{\circ}$ features ${ }^{\circ}$ are $^{\circ}$ characteristic $^{\circ}$ of $^{\circ} \mathrm{PA}^{\circ}[24]^{\circ}$ and further support the idea that the major ions observed in the tandem quadrupole product-ion spectra mainly arise from the consecutive dissociation of the $[\mathrm{M}-\mathrm{H}-$ 87] ${ }^{-}$ion, rather than from direct dissociation of the [M $\left.-{ }^{\circ} \mathrm{H}\right]^{-}{ }^{\circ}$ ions $^{\circ}$ via $^{\circ} a^{\circ}$ concerted $^{\circ}$ pathway ${ }^{\circ}[23]$.

The loss of the $\mathrm{C}_{3} \mathrm{H}_{5} \mathrm{NO}_{2}$ moiety to yield the $[\mathrm{M}-\mathrm{H}$ - 87] ${ }^{-}$ion may involve the participation of an exchangeable hydrogen that is attached to the amino group (Scheme 1, route $a$ ). This assumption is based on observation of both the $m / z 673$ and 674 ions in the IT MS $^{2}$-spectrum of $d_{2}-16: 0 / 18: 1-\mathrm{PS}^{\circ}$ at ${ }^{\circ} \mathrm{m} / z$ 762 ${ }^{\circ}$ Figure $^{\circ} 1 \mathrm{f}$ ) obtained by $\mathrm{H}-\mathrm{D}$ exchange, which occurred probably at one of the two exchangeable hydrogens of the amino 


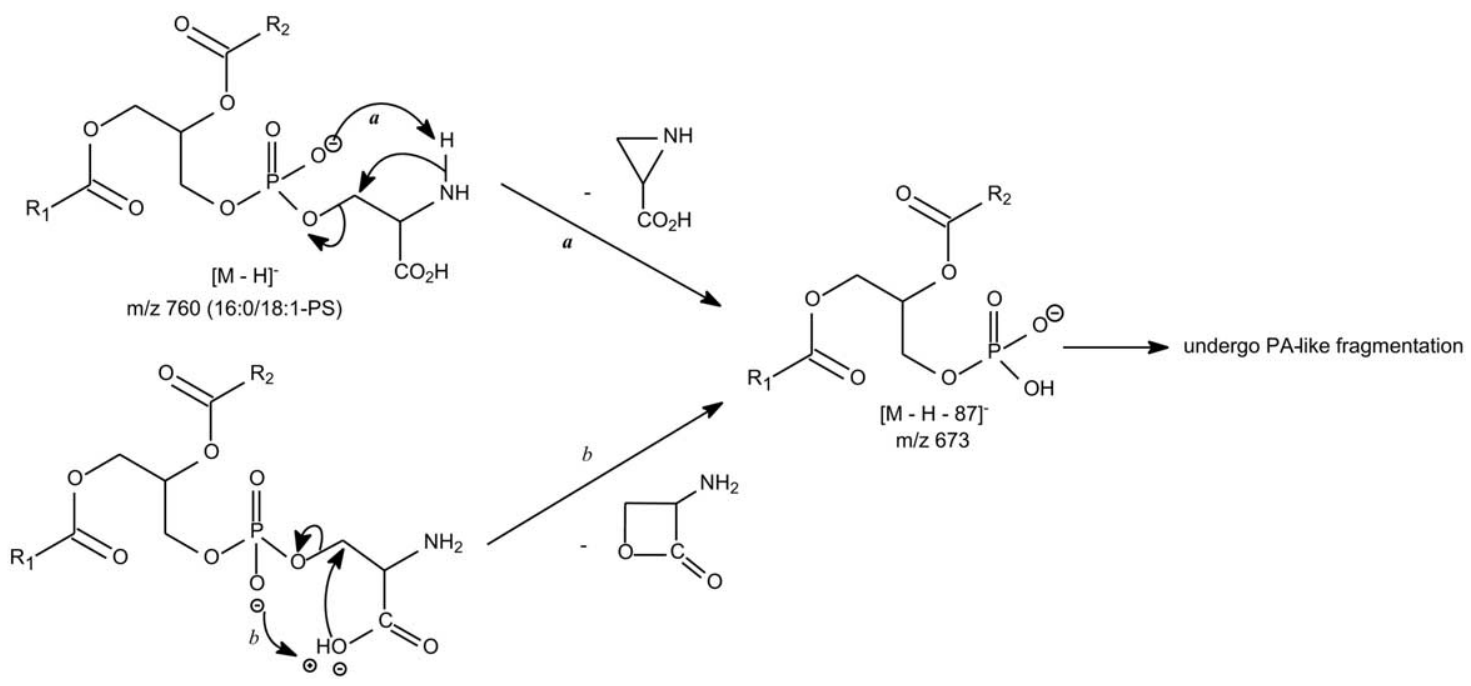

Scheme 1. The fragmentation processes proposed for the $[\mathrm{M}-\mathrm{H}]^{-}$ion of PS.

group and at the acidic hydrogen attached to carboxylate group. The loss of the $\mathrm{C}_{3} \mathrm{H}_{5} \mathrm{NO}_{2}$ moiety can also arise from the nucleophilic attack of the phosphate anionic site on the acidic hydrogen (Scheme 1 , route $b$ ) $\left[22,{ }^{\circ} 23\right] . .^{\circ}$ This $^{\circ}$ fragmentation ${ }^{\circ}$ process $^{\circ}$ is ${ }^{\circ}$ supported $^{\circ}$ by observation of both $\mathrm{m} / \mathrm{z} 673$ and 674 ions (the abundance ratio is 5 to 4 ) in the IT $\mathrm{MS}^{2}$-spectrum of $d_{1}-16$ : 0/18:1-PS at $m / z 761$ (data not shown), of which probably only the acidic hydrogen attached to the carboxylate group was replaced by a deuterium.

The $m / z 391$ ion $\left(\left[\mathrm{M}-\mathrm{H}-87-\mathrm{R}_{2} \mathrm{CO}_{2} \mathrm{H}\right]^{-}\right)$is more abundant than the $m / z 417\left(\left[\mathrm{M}-\mathrm{H}-87-\mathrm{R}_{1} \mathrm{CO}_{2} \mathrm{H}\right]^{-}\right)$ ion, and the $m / z 409$ ion $\left(\left[\mathrm{M}-\mathrm{H}-87-\mathrm{R}_{2}^{\prime} \mathrm{CH}=\mathrm{C}=\mathrm{O}\right]^{-}\right)$ is also more abundant than the $m / z 435$ ion ([M $-\mathrm{H}-87$ $\left.-\mathrm{R}_{1}{ }_{1} \mathrm{CH}=\mathrm{C}=\mathrm{O}\right]^{-}$), consistent with the notion that the ion reflecting loss of the fatty acyl substituent as an acid or as a ketene at $s n-2$ is more abundant than that arising from the analogous ${ }^{\circ}$ loss ${ }^{\circ}$ at ${ }^{\circ} \mathrm{Sn}-1{ }^{\circ}[24,25] .{ }^{\circ}$ The ${ }^{\circ} \mathrm{R}_{1} \mathrm{CO}_{2}{ }^{-}$ion at $\mathrm{m} / \mathrm{z}$ 255 is also more abundant than the $\mathrm{R}_{2} \mathrm{CO}_{2}^{-}$ion at $\mathrm{m} / z$ 281, $a^{\circ}$ characteristic ${ }^{\circ}$ feature ${ }^{\circ}$ observed $^{\circ}$ for $^{\circ} \mathrm{PA}^{\circ}[24] .^{\circ}$ The ${ }^{\circ}$ above results provide information to identify the fatty acyl substituents and their position in the glycerol backbone. The product-ion spectrum of the $[\mathrm{M}-\mathrm{H}]^{-}$ion of 18:0/ 18:1-PS at $^{\circ} \mathrm{m} / \mathrm{z} 788^{\circ}$ (Figure $\left.{ }^{\circ} 1 \mathrm{~g}\right)^{\circ}$ is $^{\circ}$ also $^{\circ}$ similar $^{\circ}$ to ${ }^{\circ}$ the product-ion spectrum of $\mathrm{m} / z 701(788 \rightarrow 701)$ generated by source CAD of $\mathrm{m} / \mathrm{z} 788$ (not shown). The primary loss of the $\mathrm{C}_{3} \mathrm{H}_{5} \mathrm{NO}_{2}$ moiety to a PA-like precursor ion pathway for the $[\mathrm{M}-\mathrm{H}]^{-}$ion of PS is also supported by the IT $\mathrm{MS}^{2}$-spectrum of the $[\mathrm{M}-\mathrm{H}]^{-}$ion of 18:0/22:6-PS at $\mathrm{m} / \mathrm{z}$

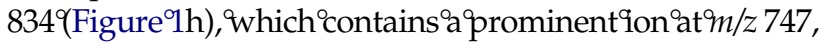

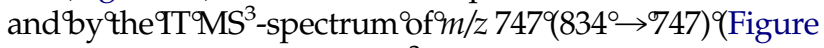
1i), ${ }^{\circ}$ which ${ }^{\circ}$ is $^{\circ} a^{\circ}$ typical $^{\circ} \mathrm{IT}^{\circ} \mathrm{MS}^{\mathrm{z}}$-spectrum ${ }^{\circ}$ of ${ }^{\circ} 18: 0 / 22: 6-\mathrm{PA}$.

The $[\mathrm{M}-2 \mathrm{H}+\mathrm{Alk}]^{-}$Ions

In contrast, the product-ion spectra of the $[\mathrm{M}-2 \mathrm{H}+\mathrm{Li}]^{-}$ ion of 16:0/18:1-PS at $m / z$ 766 ${ }^{\circ}$ obtained $^{\circ}$ witha ${ }^{\circ}{ }^{\circ}{ }^{\circ} Q^{9}$ (Figure 2a) ${ }^{\circ}$ and $^{\circ}$ with $^{\circ}$ an $^{\circ}$ ITMS $^{\circ}\left(\text { Figure }^{\circ} 2 \mathrm{~b}\right)^{\circ}$ instruments $^{\circ}$ contain major ions at $m / z 528$ and 502 arising from loss of the 16:0- and of the 18:1-fatty acyl substituents as ketenes, respectively, (Scheme 2, route $a$ ), and the ions at $m / z 484$ and 510 arising from the corresponding losses of the fatty acyl substituents as acids are of low abundance. The $m / z 502$ ion $\left(\left[\mathrm{M}-2 \mathrm{H}+\mathrm{Li}-\mathrm{R}_{2}^{\prime} \mathrm{CH}=\mathrm{CO}\right]^{-}\right)$that reflects loss of the 18:1-fatty acyl ketene at $s n-2$ is more abundant than the $m / z 528\left(\left[\mathrm{M}-2 \mathrm{H}+\mathrm{Li}-\mathrm{R}_{1}^{\prime} \mathrm{CH}=\mathrm{CO}^{-}\right)\right.$ion, reflecting loss of the 16:0-fatty acyl ketene at $s n-1$. This feature is similar to that observed for the $[\mathrm{M}-\mathrm{H}]^{-}$ion of phosphatidylethanolamines (PE), consistent with the suggestion that the gaseous $[\mathrm{M}-\mathrm{H}]^{-}$ion of $\mathrm{PE}$ is basic and undergoes more favorable loss of the fatty acid substituent $\operatorname{as}^{\circ} \mathrm{a}^{\circ} \operatorname{ketene}^{\circ} \operatorname{than}^{\circ} \operatorname{as}^{\circ} \operatorname{an}^{\circ} \operatorname{acid}^{\circ}[25]^{\circ}{ }^{\circ}$ After $^{\circ}$ the $^{\circ}$ remaining proton on the $[\mathrm{M}-\mathrm{H}]^{-}$ion of PS is replaced by an $\mathrm{Li}^{+}$, the gaseous $[\mathrm{M}-2 \mathrm{H}+\mathrm{Li}]^{-}$ion may become more basic than the $[\mathrm{M}-\mathrm{H}]^{-}$ion, and the gas-phase basicity is probably similar to that of the $[\mathrm{M}-\mathrm{H}]^{-}$ion of PE. The ions at $\mathrm{m} / \mathrm{z}$ $528\left(\left[\mathrm{M}-2 \mathrm{H}+\mathrm{Li}-\mathrm{R}_{1}{ }_{1} \mathrm{CHCO}^{-}\right)\right.$and $502([\mathrm{M}-2 \mathrm{H}+$ $\left.\mathrm{Li}-\mathrm{R}_{2}{ }_{2} \mathrm{CHCO}\right]^{-}$) are equivalent to the $[\mathrm{M}-2 \mathrm{H}+\mathrm{Li}]^{-}$ ions of 1- and 2-lysophosphatidylserine, respectively, and undergo further loss of the $\mathrm{C}_{3} \mathrm{H}_{5} \mathrm{NO}_{2}$ moiety to yield ions at $m / z 441$ and 415 , respectively, (Scheme 2, route $a_{1}^{\prime}$ ). The ions at $m / z 528$ and 502 also give rise to $m / z 417$ and 391 by elimination of serine as a lithium salt (route $a_{2}^{\prime}$ ).

The primary loss of the $\mathrm{C}_{3} \mathrm{H}_{5} \mathrm{NO}_{2}$ moiety to a $m / z 679$ ion $(766-87)$ (Scheme 2, route $b$ ), followed by loss of the 18:1-fatty acyl chain at sn-2 and loss of the 16:0-fatty acyl chain at $s n-1$ as lithium salts, respectively, gives rise to ions at $m / z 391\left(679-\mathrm{C}_{17} \mathrm{H}_{33} \mathrm{CO}_{2} \mathrm{Li}\right)$ and 417 (679 $\mathrm{C}_{15} \mathrm{H}_{31} \mathrm{CO}_{2} \mathrm{Li}$ ) (Scheme 2, route $b^{\prime}{ }_{1}$ ). Again, the $\mathrm{m} / \mathrm{z} 391$ ion is more abundant than the $m / z 417$ ion. The above results are consistent with the notion that ions reflecting the losses at $s n-2$ are more abundant than those reflecting the analogous losses at $s n-1$. The fragmentation processes are supported ${ }^{\circ}$ by $^{\circ}$ the ${ }^{\circ} \mathrm{MS}^{3}$-spectra ${ }^{\circ}$ of ${ }^{\circ} \mathrm{m} / \mathrm{z} 679^{\circ}$ (Figure ${ }^{\circ} 3 \mathrm{c}$ ), ${ }^{\circ} \mathrm{m} / \mathrm{z}$ $528^{\circ}\left(\text { Figure }^{\circ} 3 \mathrm{~d}\right)^{\circ}$ and $^{\circ} \mathrm{m} / z$ 502 ${ }^{\circ}$ not $^{\circ}$ shown).

The $\mathrm{R}_{1} \mathrm{CO}_{2}{ }^{-}$ion at $m / z 255$ is more abundant than the $\mathrm{R}_{2} \mathrm{CO}_{2}{ }^{-}$ion at $m / z 281$, similar to that observed for PA but reversed to that observed for PE. This is attributable 

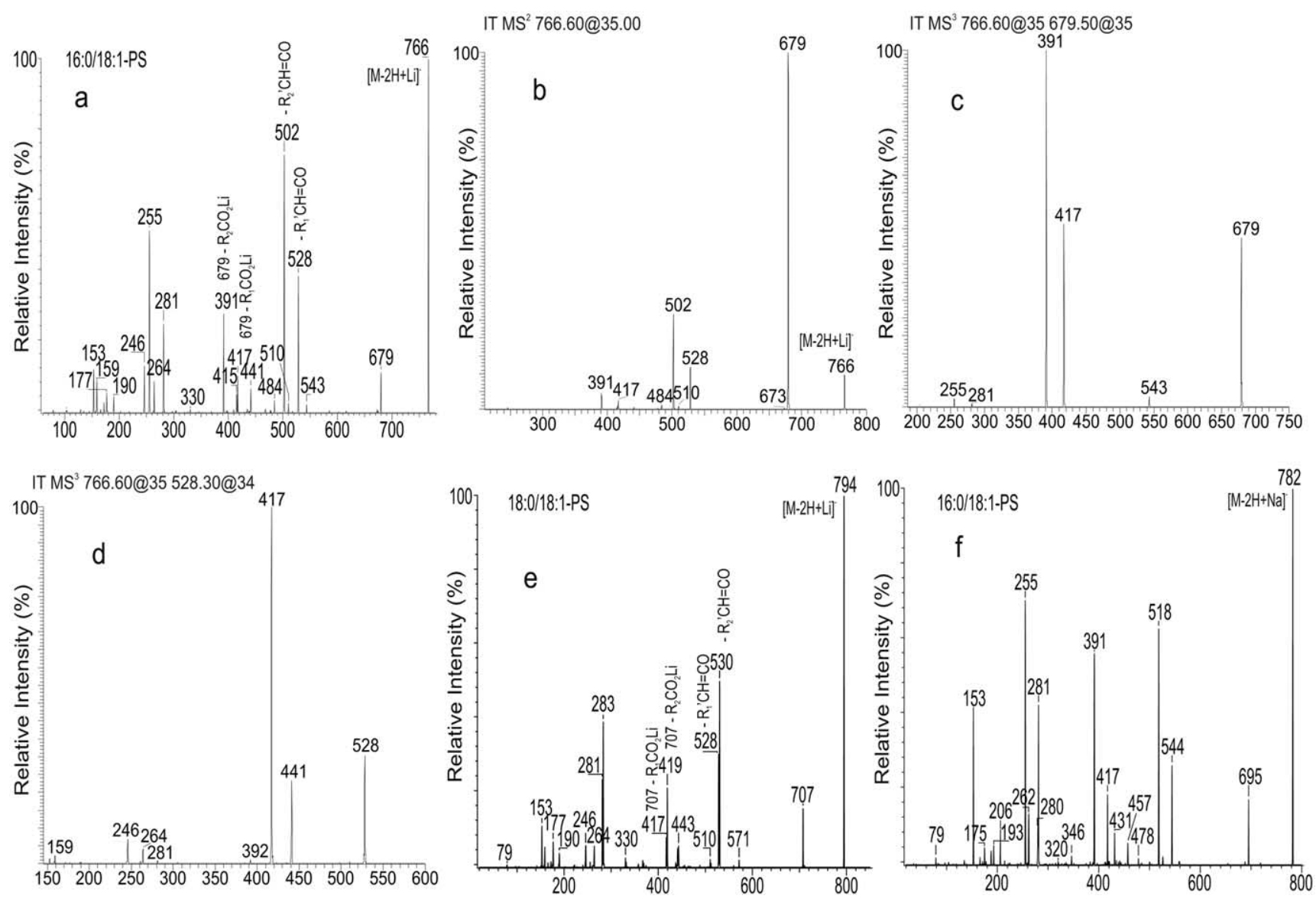

Figure 2. The product-ion spectra of the $[\mathrm{M}-2 \mathrm{H}+\mathrm{Li}]^{-}$ion of 16:0/18:1-PS at $m / z 766$ obtained with (a) a TSQ, and (b) an ITMS instruments. (c), (d) The IT MS ${ }^{3}$-spectra of (c) the $\mathrm{m} / \mathrm{z} 679(766 \rightarrow 679$ ), and (d) the $m / z 528(766 \rightarrow 528)$ ions arising from $m / z$ 766. (e), (f) The product-ion spectra of (e) the [M $2 \mathrm{H}+\mathrm{Li}^{-}$ion of 18:0/18:1-PS at $m / z 794$, and of $(\mathbf{f})$ the $[\mathrm{M}-2 \mathrm{H}+\mathrm{Na}]^{-}$ion of 16:0/18:1-PS at $\mathrm{m} / \mathrm{z}$ 782.

to the fact that the carboxylate anions at $m / z 255$ and 281 mainly arise from $\mathrm{m} / \mathrm{z} 391$ and 417, respectively, by loss of a stable dicylic glycerophosphate ester moiety of 136 (Scheme 2, route $\left.b^{\prime \prime}\right)$, as previously described for PA [24].

The combined losses of the fatty acyl substituent at $s n-2$ and at $s n-1$ as ketenes from $m / z 766$ yield the $\mathrm{m} / \mathrm{z}$ 264 ion $\left(\left[\mathrm{M}-\mathrm{H}-\mathrm{R}_{1}{ }_{1} \mathrm{CH}=\mathrm{CO}-\mathrm{R}_{2}{ }_{2} \mathrm{CH}=\mathrm{CO}\right]^{-}\right)$, which further dissociates to $\mathrm{m} / \mathrm{z} 177(264-87)$ by elimination of the $\mathrm{C}_{3} \mathrm{H}_{5} \mathrm{NO}_{2}$ moiety, while the $\mathrm{m} / z 246$ ion ([M - H $\left.-\mathrm{R}_{1}{ }_{1} \mathrm{CH}=\mathrm{CO}-\mathrm{R}_{2}{ }_{2} \mathrm{CO}_{2} \mathrm{H}\right]^{-}+\left[\mathrm{M}-\mathrm{H}-\mathrm{R}_{2}{ }_{2} \mathrm{CH}=\mathrm{CO}\right.$ $\left.-\mathrm{R}^{\prime}{ }_{1} \mathrm{CO}_{2} \mathrm{H}\right]^{-}$) arises from primary loss of a fatty acyl substituent as a ketene followed by loss of the remaining fatty acyl substituent as an acid. These fragmentation pathways are supported by observation of the ions at $\mathrm{m} / \mathrm{z} 264$ and 246 in the $\mathrm{MS}^{3}$-spectrum of $\mathrm{m} / \mathrm{z} 528$ (Figure $2 \mathrm{~d}$ ). . Ions $^{\circ}$ characteristic $^{\circ}$ to $^{\circ}$ serine ${ }^{\circ}$ head ${ }^{\circ}$ group ${ }^{\circ}$ are observed at $m / z 190$, arising from cleavage of the C3-O bond (Scheme 2, route $c$ ), via the fragmentation process similar ${ }^{\circ}$ to ${ }^{\circ}$ that ${ }^{\circ}$ previously ${ }^{\circ}$ observed ${ }^{\circ}$ for ${ }^{\circ} \mathrm{PE}^{\circ}[25] .{ }^{\circ}$ The analogous ions from the fragmentation processes are also observed in the product-ion spectra of the $[\mathrm{M}-2 \mathrm{H}$

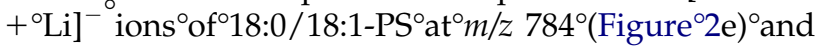

the $[\mathrm{M}-2 \mathrm{H}+\mathrm{Na}]^{-}$ion of the 16:0/18:1-PS at $m / z 782$ (Figure $2 \mathrm{f}$ ).

The $[\mathrm{M}+\mathrm{H}]^{+}$ions

Both the $\mathrm{MS}^{2}$-spectra of the $[\mathrm{M}+\mathrm{H}]^{+}$ion of $16: 0 / 18$ : 1-PS ${ }^{\circ}$ at $^{\circ} \mathrm{m} / z$ 762 ${ }^{\circ}$ obtained $^{\circ}$ with $^{\circ} \mathrm{a}^{\circ} \mathrm{TSQ}^{\circ}$ (Figure $\left.^{\circ} 3 \mathrm{a}\right)^{\circ}$ and with an ITMS (not shown) instruments are dominated by a $[\mathrm{M}+\mathrm{H}-185]^{+}$ion at $m / z 577(762-185)$ arising from loss of the phosphoserine moiety (Scheme 3), similar to that previously observed by FAB tandem mass spectrometry, and provides limited information for ${ }^{\circ}$ structural ${ }^{\circ}$ characterization ${ }^{\circ}[21] .^{\circ}$ Although ${ }^{\circ}$ the ${ }^{\circ}$ identities of the fatty acyl substituents can be recognized by the 16:0- and 18:1-acylium ions at $\mathrm{m} / \mathrm{z} 239$ and 265, respectively, as well as by the ions at $\mathrm{m} / \mathrm{z} 339$ and 313 arising from losses of the 16:0- and the 18:1-fatty acyl substituents as ketenes from $m / z 577$, respectively, these ions are of low abundance and lack the specificity for assignment of the position of the fatty acyl substituents on the glycerol backbone.

In contrast, the IT $\mathrm{MS}^{3}$-spectrum of the $\mathrm{m} / \mathrm{z} 577$ $\left(762^{\circ} \rightarrow^{\circ} 577\right)^{\circ}$ ion $^{\circ}\left(\text { Figure }^{\circ} 3 \mathrm{~b}\right)^{\circ}$ contains $^{\circ} \mathrm{a}^{\circ}$ prominent 


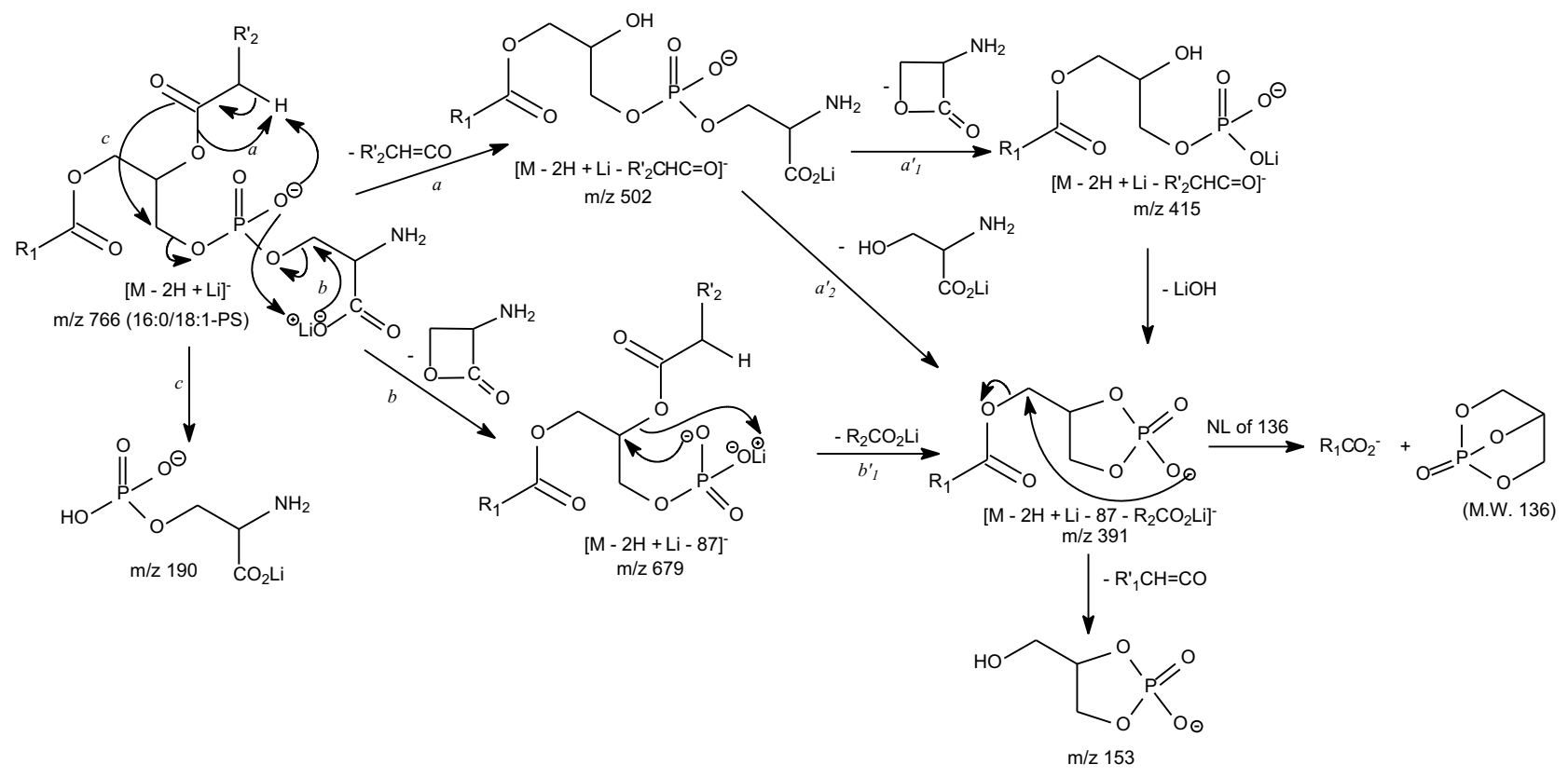

Scheme 2. The fragmentation processes proposed for the $[\mathrm{M}-2 \mathrm{H}+\mathrm{Li}]^{-}$ion of PS. Only the preferential pathways involving the participation of the fatty acid substituent at $s n-2$ are shown. The $m / z$ values are those observed for 16:0/18:1-PS.

18:1-acylium ion at $m / z 265$, which is more abundant than the 16:0-acylium at $\mathrm{m} / \mathrm{z} 239$, along with ion at $\mathrm{m} / \mathrm{z}$ $247\left(265-\mathrm{H}_{2} \mathrm{O}\right)$, which is also more abundant than the $m / z 221\left(239-\mathrm{H}_{2} \mathrm{O}\right)$ ion. The spectrum also contains the $m / z 321$ ion $\left(577-\mathrm{R}_{1} \mathrm{CO}_{2} \mathrm{H}\right)$ arising from further loss of the 16:1-fatty acid substituent at $s n-1$, whereas the analogous ion expected at $m / z 295$ arising from loss of the 18:1-fatty acid at $s n-2$ is not present. The drastic differences in the abundances of the above ion pairs resulting from differential losses of the fatty acyl substituents provide information for assignment of the positions of the fatty acyl moieties on the glycerol backbone. Similar results were also observed for the $\mathrm{MS}^{3}$-spectrum ${ }^{\circ}$ of $^{\circ} \mathrm{m} / \mathrm{z} \quad 605^{\circ}\left(790^{\circ} \rightarrow{ }^{\circ} 605\right)^{\circ}\left(\right.$ Figure $^{\circ} 3 \mathrm{c}$ ), arising from 18:0/18:1-PS at $m / z$ 790. However, the IT $\mathrm{MS}^{3}$-spectrum ${ }^{\circ}$ of the $m / z$ 6519on $\left(836^{\circ} \rightarrow\right.$ 651) ${ }^{\circ}$ (Figure $3 \mathrm{~d}$ ) arising from 18:0/22:6-PS at $m / z 836$ is dominated by ions at $m / z 367$ attributable to the loss of the 18:0-fatty acyl moiety at $s n-1$, and at $m / z 341$ due to loss of the 22:6-fatty ${ }^{\circ}$ acyl $^{\circ}$ substituent $^{\circ}$ as $^{\circ} \mathrm{a}^{\circ}$ ketene. $^{\circ}$ The $^{\circ}$ preferential loss of polyunsaturated fatty acid moiety as a ketene has ${ }^{\circ}$ been ${ }^{\circ}$ previously ${ }^{\circ}$ bserved $^{\circ}$ for ${ }^{\circ} \mathrm{PE}^{\circ}$ and ${ }^{\circ} \mathrm{PC}^{\circ}\left[26,{ }^{\circ} 27\right]$.

\section{The $[M+A l k]^{+}$Ions}

The use of alkali metal adduct ions, in particular the [M $+\mathrm{Li}]^{+}$ions, for structural characterization of various lipids by ESI coupled with tandem mass spectrometry has ${ }^{\circ}$ been ${ }^{\circ}$ very ${ }^{\circ}$ successful $^{\circ}\left[26^{\circ}-29\right]$. $^{\circ}$ The $^{\circ} \mathrm{MS}^{2}$-spectrum ${ }^{\circ}$ of the $[\mathrm{M}+\mathrm{Li}]^{+}$ion of 16:0/18:1-PS at $\mathrm{m} / \mathrm{z} 768$ obtained with ${ }^{\circ} \mathrm{a}^{\circ} \mathrm{TSQ}^{\circ}{ }^{\circ}$ instrument ${ }^{\circ}\left(\text { Figure }^{\circ} 4 \mathrm{a}\right)^{\circ}$ contains $^{\circ}$ prominent ions at $m / z 577$, arising from loss of phosphoserine as a lithium salt and at $m / z 192$, corresponding to a lithiated phosphoserine ion, via cleavage of the $\mathrm{C} 3-\mathrm{OP}$ bond similar to that observed for the $[\mathrm{M}+\mathrm{H}]^{+}$ion (Scheme $3)$. The ion at $m / z 681\left(768-\mathrm{C}_{3} \mathrm{H}_{5} \mathrm{NO}_{2}\right)$ is of lowabundance and gives rise to ions at $\mathrm{m} / \mathrm{z} 425$ (681 $\left.\mathrm{R}_{1} \mathrm{CO}_{2} \mathrm{H}\right)$ and $399\left(681-\mathrm{R}_{2} \mathrm{CO}_{2} \mathrm{H}\right)$ by loss of the 16:0and 18:1-fatty acid, respectively. The $m / z 425$ ion is more abundant than the $m / z 399$ ion, similar to that observed for the $\left[\mathrm{M}^{\circ}+\mathrm{Ci}^{+}{ }^{\circ}{ }^{\circ}\right.$ ion of 9 phosphatidylethanolamine [26], and provides information for assignment of the position of the fatty acyl substituents on the glycerol backbone. Similar results were also observed for the $[\mathrm{M}+\mathrm{Li}]^{+}$ion of ${ }^{\circ} 18: 0 / 18: 1-$ PS $^{\circ}$ at $^{\circ} \mathrm{m} / z$ 796 ${ }^{\circ}$ (Figure ${ }^{\circ} 4 \mathrm{~b}$ ).

The IT $\mathrm{MS}^{2}$-spectrum of the $[\mathrm{M}+\mathrm{Li}]^{+}$of $16: 0 / 18$ : 1-PS at ${ }^{\circ} \mathrm{m} / \mathrm{z} 768^{\circ}\left(\text { Figure }^{\circ} 4 \mathrm{c}\right)^{\circ}$ contains $^{\circ}$ ions ${ }^{\circ}$ similar to those observed ${ }^{\circ}$ in $^{\circ}$ Figure $^{\circ} 4 \mathrm{a},{ }^{\circ}$ but $^{\circ}$ the ${ }^{\circ}$ ions $^{\circ}$ at $^{\circ} \mathrm{m} / z 681^{\circ}$ and $^{\circ} 670$ are ${ }^{\circ}$ mong ${ }^{\circ}$ the ${ }^{\circ} \operatorname{most}^{\circ}$ prominent. ${ }^{\circ}$ As ${ }^{\circ}$ shown $^{\circ}{ }^{\circ}{ }^{\circ}$ Figure $^{\circ} 4 \mathrm{~d}$, the $\mathrm{MS}^{3}$-spectrum of the $m / z 681$ ion $(768 \rightarrow 681)$ yields ions at $\mathrm{m} / \mathrm{z} 583$ and 577 arising from loss of the phosphoric acid group as an acid and as a lithium salt, respectively. The spectrum also contains ions at $m / z 425$ $\left(681-\mathrm{R}_{1} \mathrm{CO}_{2} \mathrm{H}\right)$ and $399\left(681-\mathrm{R}_{2} \mathrm{CO}_{2} \mathrm{H}\right)$ resulting from loss of the 16:0- and 18:1-fatty acid moiety, respectively, along with ions at $m / z 443\left(681-\mathrm{R}_{1}{ }_{1} \mathrm{CH}=\mathrm{CO}\right)$ and $417\left(681-\mathrm{R}_{2}^{\prime} \mathrm{CH}=\mathrm{CO}\right)$, arising from the corresponding losses as fatty acyl ketenes.

The ${ }^{\circ}$ prominence ${ }^{\circ}$ of ${ }^{\circ}$ the ${ }^{\circ}$ ion $^{\circ}$ at ${ }^{\circ} \mathrm{m} / z$ 670 ${ }^{\circ}$ in $^{\circ}$ Figure $^{\circ} 4 \mathrm{c}^{\circ}$ is of interest. The ion corresponds to loss of the phosphoric acid and its formation may involve a rearrangement process in which the anionic site of the serine head group renders nucleophilic attack on C-3 of the glycerol backbone, followed by expulsion of the phosphoric acid moiety to yield a lithiated triacyl glycerol-like ion at $\mathrm{m} / \mathrm{z}$ 670 (Scheme 4). This fragmentation process is sup- 

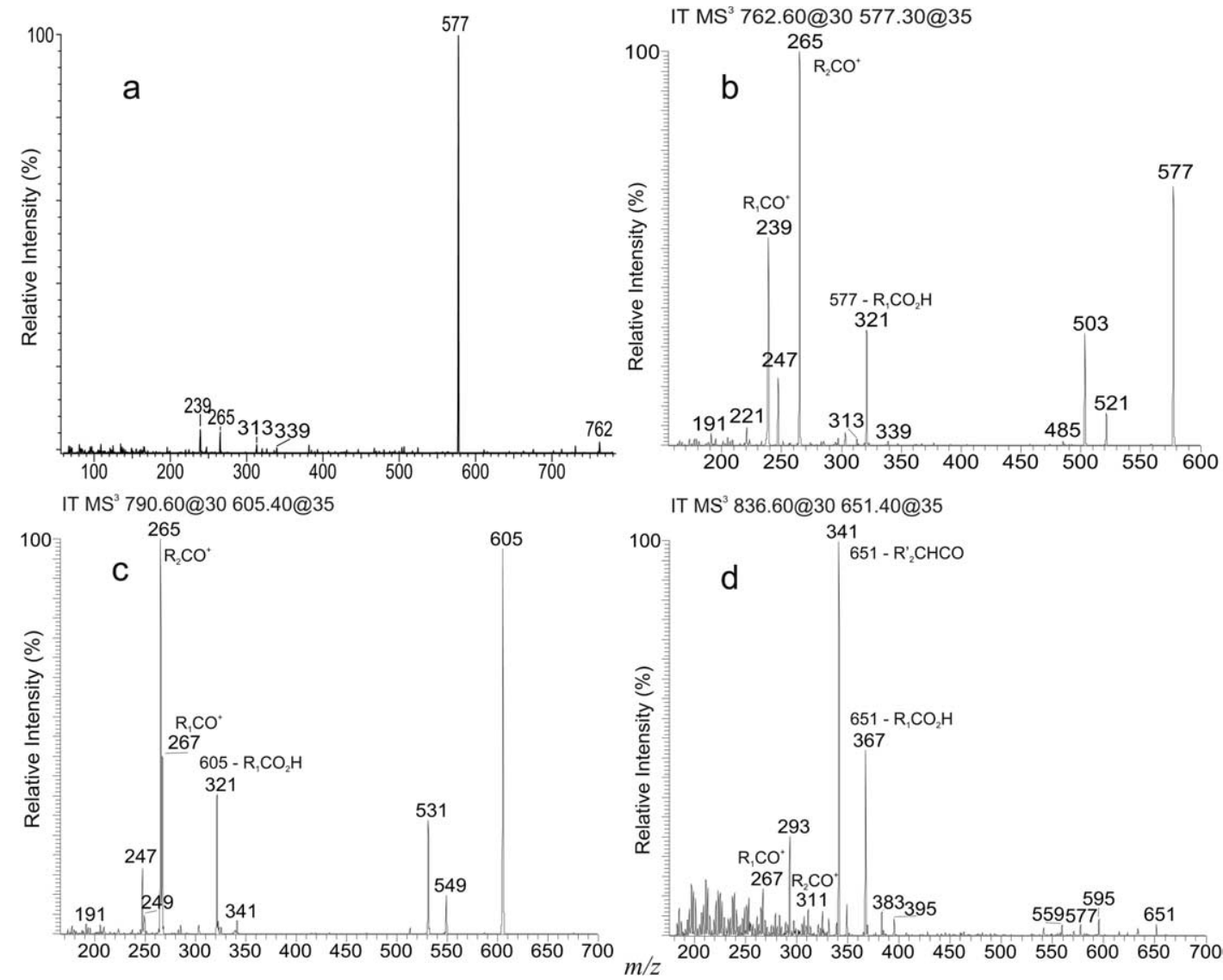

Figure 3. (a) The tandem quadrupole product-ion spectrum of the $[\mathrm{M}+\mathrm{H}]^{+}$ion of 16:0/18:1-PS at $m / z$ 762. (b)-(d) The IT MS ${ }^{3}$-spectra of $(\mathbf{b})$ the $m / z 577$ ion $(762 \rightarrow 577)$ arising from 16:0/18:1-PS, of (c) the $m / z 605$ ion $(790 \rightarrow 605)$ arising from 18:0/18:1-PS, and of $(\mathbf{d})$ the $m / z 651$ ion $(836 \rightarrow 651)$ arising from 18:0/22:6-PS.

ported $^{\circ}$ by $^{\circ}$ the $^{\circ} \mathrm{MS}^{3}$-spectrum ${ }^{\circ}$ of ${ }^{\circ} \mathrm{m} / z 670^{\circ}$ (Figure $^{\circ} 4 \mathrm{e}$ ), which contains ions at $m / z 583$ and 577, corresponding to loss of $\mathrm{C}_{3} \mathrm{H}_{5} \mathrm{NO}_{2}$ and $\mathrm{C}_{3} \mathrm{H}_{4} \mathrm{NO}_{2} \mathrm{Li}$ (as a lithium salt) moieties (Scheme $4 \mathrm{a}$, route $a$ ), respectively; and ions at $\mathrm{m} / \mathrm{z} 414$ (route $b$ ) and 388 resulting from the respective loss of the 16:0- and of the 18:1-fatty acid moieties. In contrast, the ion at $\mathrm{m} / \mathrm{z} 670$ is of low abundance in the product-ion spectrum obtained with a TSQ instrument (Figure $\left.{ }^{\circ} 4 a\right){ }^{\circ}$ This $^{\circ}$ is ${ }^{\circ}$ consisten $^{\circ}{ }^{\circ}$ with $^{\circ}$ the ${ }^{\circ}$ suggestion ${ }^{\circ}$ that elimination of the phosphate moiety involves a rear-

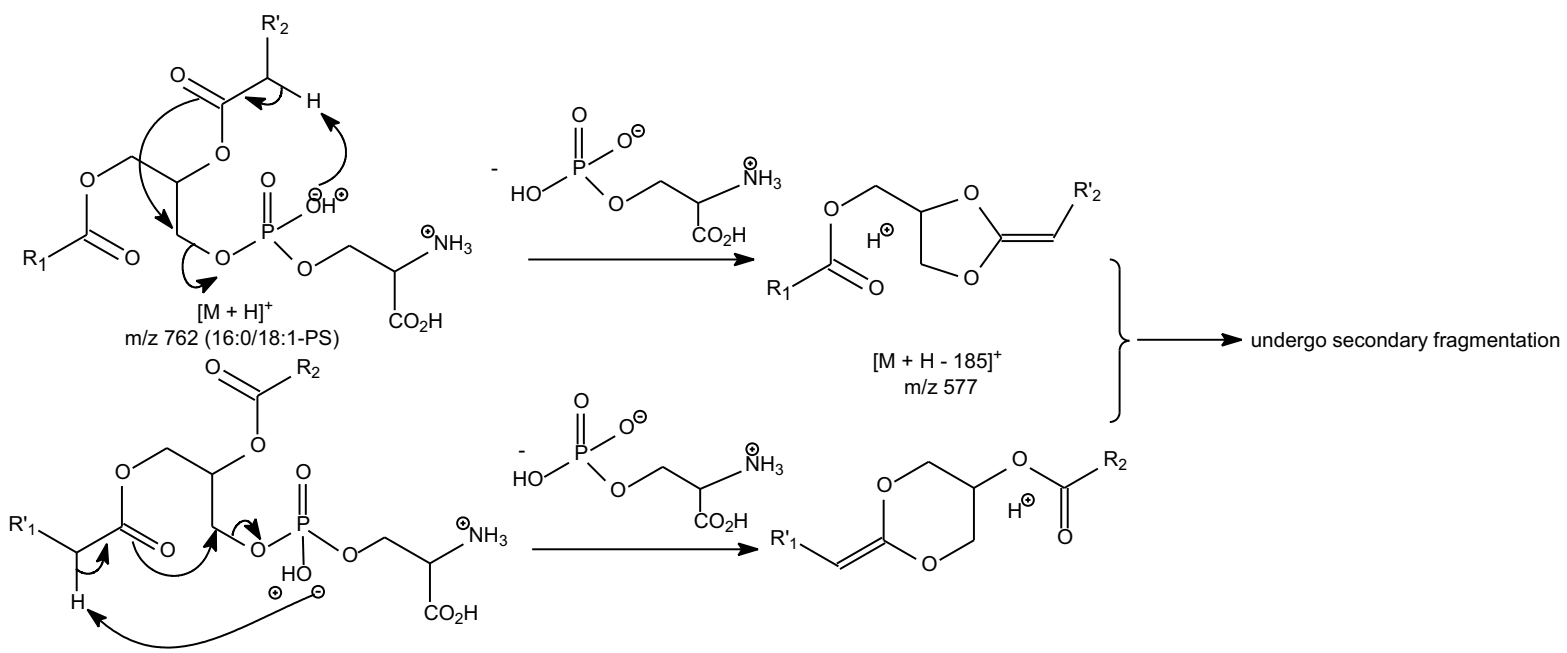

Scheme 3. The fragmentation processes proposed for the $[\mathrm{M}+\mathrm{H}]^{+}$ion of 16:0/18:1-PS. 

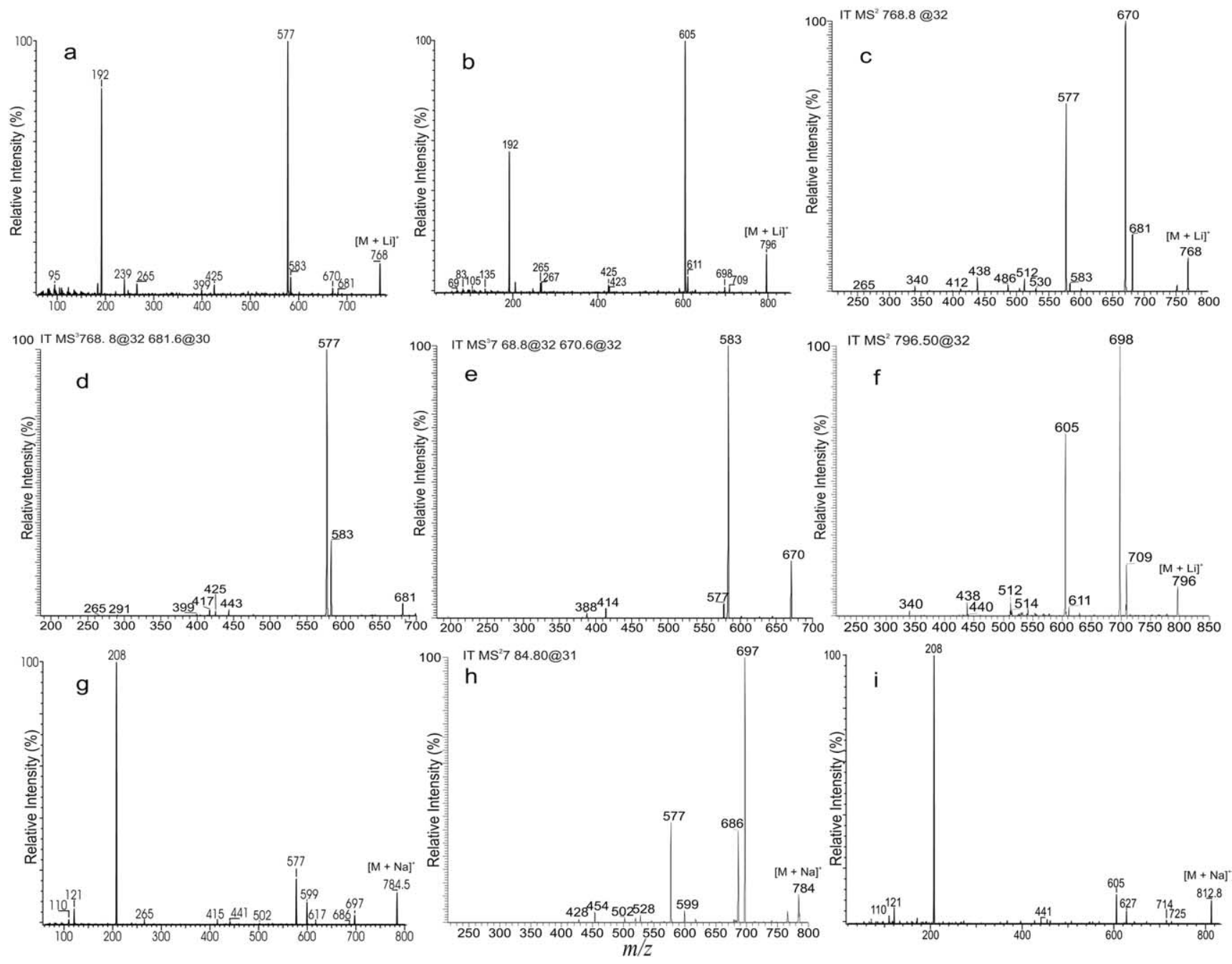

Figure 4. The tandem quadrupole product-ion spectra of the $[\mathrm{M}+\mathrm{Li}]^{+}$ions of (a) 16:0/18:1-PS at $\mathrm{m} / \mathrm{z}$ 768, and of (b) 18:0/18:1-PS at $\mathrm{m} / z$ 796. (c)-(e) The IT $\mathrm{MS}^{2}$-spectra of the $[\mathrm{M}+\mathrm{Li}]^{+}$ions of (c) 16:0/18:1-PS at $m / z 768$, and its IT MS ${ }^{3}$-spectra of (d) $m / z 681$ ion $(768 \rightarrow 681)$, and (e) $m / z 670$ ion $(768$ $\rightarrow 670$ ). (f) The IT $\mathrm{MS}^{2}$-spectrum of the $\left[\mathrm{M}+\mathrm{Li}^{+}\right.$ion of 18:0/18:1-PS at $\mathrm{m} / z$ 796. (g)-(i) The product-ion spectra of the $\left[\mathrm{M}+\mathrm{Na}^{+}\right.$ions of 16:0/18:1-PS at $\mathrm{m} / \mathrm{z} 784$ obtained with $(\mathrm{g})$ a TSQ instrument, (h) an ITMS instrument, and (i) of 18:0/18:1-PS at $\mathrm{m} / \mathrm{z} 812$ obtained with a TSQ instrument.

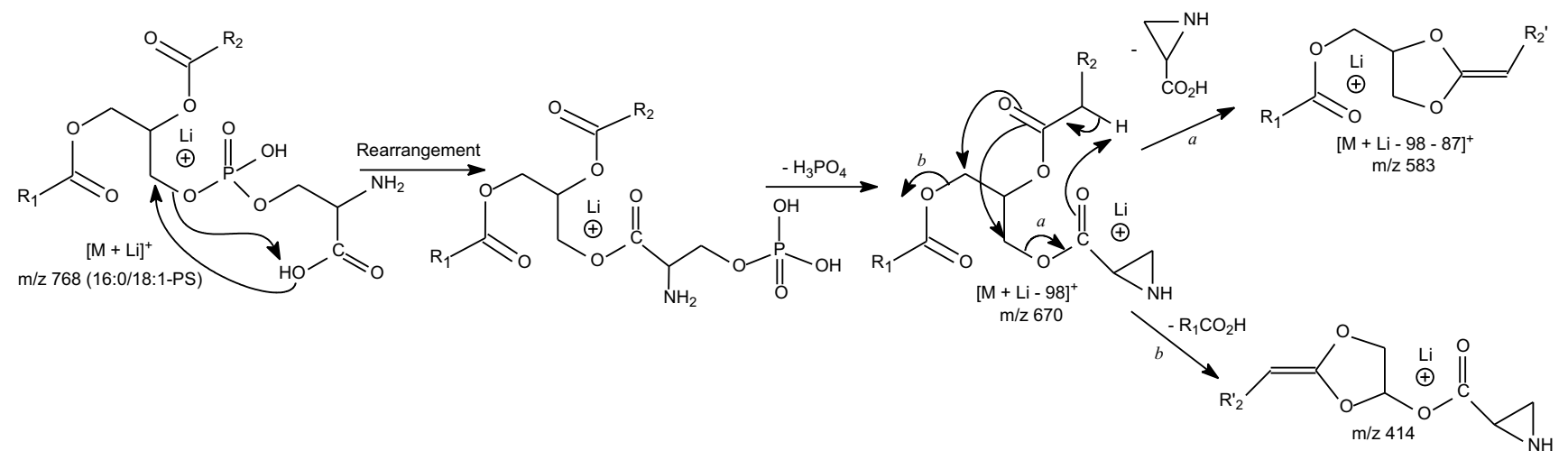

Scheme 4. The fragmentation pathways leading to internal loss of phosphate group proposed for the $[\mathrm{M}+\mathrm{Li}]^{+}$ion of PS. The $m / z$ values observed for 16:0/18:1-PS are also shown. 
rangement process, which is favored by ITMS but less observable for TSQ because of its multiple collision nature that leads to further fragmentation.

In $^{\circ}$ Figure $^{\circ} 4 \mathrm{c},{ }^{\circ}$ the ${ }^{\circ}$ spectrum $^{\circ}$ also ${ }^{\circ}$ contains $^{\circ}$ ions ${ }^{\circ}$ at ${ }^{\circ} \mathrm{m} / z$ 512 and 486, reflecting losses of the 16:0- and 18:1-acid substituents, respectively, and ions at $m / z 438$ and 412, corresponding to loss of a 1-palmitorylglycerol and of a 2-oleorylglycerol moieties, respectively. These latter two ions are not present in the TSQ product-ion spec$\operatorname{trum}^{\circ}\left(\right.$ Figure $\left.^{\circ} 4 \mathrm{a}\right)$, ${ }^{\circ}$ and $^{\circ}$ the $^{\circ}$ origin $^{\circ}$ of $^{\circ}$ these $^{\circ}$ two $^{\circ}$ ions $^{\circ}$ may also involve a rearrangement process followed by loss of an acylglycerol. Again, the features that the $\mathrm{m} / \mathrm{z} 512$ (768 $-\mathrm{R}_{1} \mathrm{CO}_{2} \mathrm{H}$ ) ion is more abundant than the $m / z 486$ $\left(768-\mathrm{R}_{2} \mathrm{CO}_{2} \mathrm{H}\right)$ ion, and that the $\mathrm{m} / \mathrm{z} 438$ (768 $\left.\mathrm{R}_{1} \mathrm{CO}_{2} \mathrm{CH}_{2} \mathrm{CH}(\mathrm{OH}) \mathrm{CH}_{2} \mathrm{OH}\right)$ ion is more abundant than the $m / z 412\left(768-\mathrm{HOCH}_{2} \mathrm{CH}\left(\mathrm{OCOR}_{2}\right) \mathrm{CH}_{2} \mathrm{OH}\right)$ ion provide information for assignment of the position of the fatty acyl substituents on the glycerol backbone. Similar results were also observed for the $[\mathrm{M}+\mathrm{Li}]^{+}$ion of $^{\circ} 18: 0 / 18: 1-$ PS $^{\circ}$ at $^{\circ} \mathrm{m} / z$ 796 ${ }^{\circ}$ (Figure ${ }^{\circ} 4 \mathrm{f}$ ).

The product-ion spectrum of the $[\mathrm{M}+\mathrm{Na}]^{+}$ion of 16:0/18:1-PS ${ }^{\circ}$ at $^{\circ} \mathrm{m} / \mathrm{z} 784^{\circ}$ (Figure $\left.^{\circ} 4 \mathrm{~g}\right)^{\circ}$ contains $^{\circ}$ ions analogous ${ }^{\circ}$ to $^{\circ}$ those $^{\circ}$ observed $^{\circ}$ in $^{\circ}$ Figure $^{\circ} 4 \mathrm{a},{ }^{\circ}$ however, the ${ }^{\circ}$ spectrum is ${ }^{\circ}$ dominated by $^{\circ} \mathrm{m} / \mathrm{z} 208$, ${ }^{\circ}$ corresponding to a sodiated phosphoserine, and the ion at $m / z 577$ is of $^{\circ}$ low $^{\circ}$ abundance. ${ }^{\circ}$ The $^{\circ}$ results $^{\circ}$ may $^{\circ}$ indicate ${ }^{\circ}$ that cleavage of the C3-OP bond to form the sodiated phosphoserine ion at $\mathrm{m} / \mathrm{z} 208$ ([phosphoserine + $\mathrm{Na}^{+}$) becomes more competitive than formation of a protonated $[\mathrm{M}+\mathrm{Na}-207]^{+}$ion at $m / z 577$, as the $\mathrm{Li}^{+}$ was replaced by $\mathrm{Na}^{+}$(Scheme $4 \mathrm{~b}$ ). This is consistent with the earlier findings that the product-ion spectrum of the $[\mathrm{M}+\mathrm{H}]^{+}$ion of $16: 0 / 18: 1-P S$ is dominated by $m / z 577$ (Scheme 3 ) and a protonated phosphoserine ${ }^{\circ}$ ion $^{\circ}$ expected $^{\circ}$ at $^{\circ} \mathrm{m} / z{ }^{2} 186^{\circ}$ is $^{\circ}$ absent $^{\circ}$ (Figure 3a). ${ }^{\circ} \mathrm{The}^{\circ} \mathrm{IT}^{\circ} \mathrm{MS}^{2^{\circ}}$-spectrum ${ }^{\circ}$ of ${ }^{\circ}$ the $^{\circ}\left[\mathrm{M}^{\circ}+{ }^{\circ} \mathrm{Na}\right]^{+}{ }^{\circ}$ ion ${ }^{\circ}$ of 16:0/18:1-PS ${ }^{\circ}$ at $^{\circ} \mathrm{m} / \mathrm{z} 784^{\circ}$ (Figure $\left.^{\circ} 4 \mathrm{~g}\right)^{\circ}$ contains $^{\circ}$ ions analogous ${ }^{\circ}$ to $^{\circ}$ those ${ }^{\circ}$ observed ${ }^{\circ}{ }^{\circ}{ }^{\circ} F^{2}$ igure ${ }^{\circ} 4 c$, but ${ }^{\circ}$ the ${ }^{\circ}$ ion at $m / z 686$ from loss of the phosphoric acid moiety declines and the ion at $\mathrm{m} / \mathrm{z} 697$ reflecting loss of the $\mathrm{C}_{3} \mathrm{H}_{5} \mathrm{NO}_{2}$ moiety becomes the most prominent. Similar results were also observed for the $[\mathrm{M}+\mathrm{Na}]^{+}$ion of $18: 0 / 18: 1-P S$ at $m / z \quad 812$ obtained with a TSQ

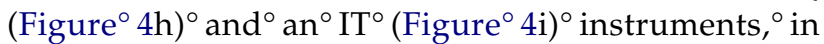
which the $[\mathrm{M}+\mathrm{Na}-87]^{+}$ion at $m / z 725$ is more abundant than $m / z 714\left(\left[\mathrm{M}+\mathrm{Na}-\mathrm{H}_{3} \mathrm{PO}_{4}\right]^{+}\right)$. These results also demonstrate that the phosphoric acid moiety is more competitive than its complementary $\left[\mathrm{M}-\mathrm{H}_{3} \mathrm{PO}_{4}\right]$ moiety for $\mathrm{Na}^{+}$to form a sodiated ion, following cleavage of the phosphoric acid moiety. The results are also consistent with the notion that the $m / z 121$ ion $\left(\left[\mathrm{H}_{3} \mathrm{PO}_{4}+\mathrm{Na}\right]^{+}\right)$is more abundant than the $\left[\mathrm{M}+\mathrm{Na}-\mathrm{H}_{3} \mathrm{PO}_{4}\right]^{+}$ion at $m / z 686$ or at $m / z 714$ in $^{\circ}$ the ${ }^{\circ}$ product-ion ${ }^{\circ}$ spectrum ${ }^{\circ}$ of $^{\circ} \mathrm{m} / z 7^{\circ} 4^{\circ}$ (Figure $4 \mathrm{f}$ ) ${ }^{\circ}$ or of $^{\circ} \mathrm{m} / \mathrm{z} 812^{\circ}$ (Figure $\left.{ }^{\circ} 4 \mathrm{i}\right)$. $^{\circ}$ In $^{\circ}$ contrast, ${ }^{\circ}$ the ${ }^{\circ}$ analogous ${ }^{\circ}$ ion expected at $m / z 105\left(\left[\mathrm{H}_{3} \mathrm{PO}_{4}+\mathrm{Li}\right]^{+}\right)$is nearly absent in the product-ion spectra arising from the $[\mathrm{M}+\mathrm{Li}]^{+}$ ion $^{\circ}$ (Figure ${ }^{\circ} \mathrm{a}^{\circ}$ and $^{\circ} \mathrm{b}$ ).

\section{The $[M-H+2 A l k]^{+}$Ions}

The CAD product-ion spectrum of the $[\mathrm{M}-\mathrm{H}+2 \mathrm{Li}]^{+}$ ion ${ }^{\circ}{ }^{\circ} 16: 0 / 18: 1-\mathrm{PS}^{\circ}$ at $^{\circ} \mathrm{m} / z 7^{\circ} 4^{\circ}$ (Figure $\left.{ }^{\circ} 5 \mathrm{a}\right)^{\circ}$ is ${ }^{\circ}$ dominated by the $m / z 687$ ion, arising from loss of 87 as described earlier. The cleavage of the $\mathrm{C} 3-\mathrm{OP}$ bond similar to that observed for the $[\mathrm{M}+\mathrm{H}]^{+}$ion (Scheme 3) results in ions at $m / z$ 577, reflecting loss of the phosphoserine moiety as a dilithium salt, and at $m / z 198$, corresponding to a dilithiated phosphoserine ion. The ions at $\mathrm{m} / \mathrm{z}$ $431(687-256)$ and $405(687-282)$, arise from further losses of the 16:0- and the 18:1-fatty acids from $m / z$ 687, respectively. The fact that the $m / z 431$ ion reflecting loss of the fatty acid moiety at $s n-1$ is more abundant than the $m / z \quad 405$ ion reflecting the analogous loss at $s n-2$ provides ${ }^{\circ}$ information ${ }^{\circ}$ for $^{\circ}$ assignment $^{\circ}$ of ${ }^{\circ}$ the ${ }^{\circ}$ position $^{\circ}$ of the fatty acyl substituents. The IT $\mathrm{MS}^{2}$-spectrum of the $\left[\mathrm{M}^{\circ}-{ }^{\circ} \mathrm{H}^{\circ}+{ }^{\circ} 2 \mathrm{Li}\right]^{+}{ }^{\circ}$ ion ${ }^{\circ}$ of ${ }^{\circ} 16: 0 / 18: 1-\mathrm{PS}^{\circ}$ at ${ }^{\circ} \mathrm{m} / \mathrm{z} 774^{\circ}$ (Figure $5 b)^{\circ}$ is $^{\circ}{ }^{\circ} s^{\circ}{ }^{\circ}$ dominated $^{\circ}$ by $^{\circ}$ the ${ }^{\circ}$ ion ${ }^{\circ}$ at $^{\circ} \mathrm{m} / z$ 687 $67^{\circ}\left(774^{\circ}-{ }^{\circ} 87\right)$. The consecutive fragmentation process to yield ions at $m / z 431$ and 405 is supported by the IT $\mathrm{MS}^{3}$-spectrum of the ${ }^{\circ} m / z$ 687 ${ }^{\circ}$ ion $^{\circ}\left(774^{\circ} \rightarrow{ }^{\circ} 687\right)^{\circ}\left(\right.$ Figure $\left.^{\circ} 5 \mathrm{c}\right)$. $^{\circ}$ The $^{\circ}\left[\mathrm{M}^{\circ}-{ }^{\circ} \mathrm{H}^{\circ}+\right.$ $2 \mathrm{Li}^{+}{ }^{+}$ion $^{\circ}$ of $^{\circ} 18: 0 / 22: 6-$ PS $^{\circ}$ at $^{\circ} \mathrm{m} / z$ 848 ${ }^{\circ}$ (Figure ${ }^{\circ} 5 \mathrm{~d}$ ) ${ }^{\circ}$ is ${ }^{\circ}$ also dominated by $m / z 761$ and contains major ions at $m / z$ $477(761$ - 284) and $433(61$ - 328) from further losses of the 18:0-fatty acyl moiety at $s n-1$ and the 22:6-fatty acyl substituent at $s n-2$, respectively.

The product-ion spectrum of the $[\mathrm{M}-\mathrm{H}+2 \mathrm{Na}]^{+}$ ion ${ }^{\circ}{ }^{\circ} 16: 0 / 18: 1-$ PS $^{\circ}$ at $^{\circ} \mathrm{m} / z$ 806 ${ }^{\circ}$ (Figure ${ }^{\circ}$ e) ${ }^{\circ}$ obtained ${ }^{\circ}$ with a TSQ instrument contains ions analogous to those observed $^{\circ}$ in $^{\circ}$ Figure $^{\circ} 5 \mathrm{a}^{\circ}{ }^{\circ}$ and $^{\circ}$ the $^{\circ}$ spectrum ${ }^{\circ}$ is ${ }^{\circ}$ dominated by the $m / z 719(806-87)$ ion. However, the $m / z 577$ ion is $^{\circ}$ less $^{\circ}$ abundant ${ }^{\circ}$ than $^{\circ}$ that $^{\circ}$ observed $^{\circ}$ in ${ }^{\circ}$ Figure $^{\circ} 5 \mathrm{a},{ }^{\circ}$ and the ion at $m / z 230\left(\left[\mathrm{NaHPO}_{3} \mathrm{OCH}_{2} \mathrm{CH}\left(\mathrm{CO}_{2}\right) \mathrm{NH}_{2}+\right.\right.$ $\mathrm{Na}]^{+}$), a sodiated ion of a sodium phosphoserine becomes more abundant than the analogous ion at $m / z 198$ $\left(\left[\mathrm{LiHPO}_{3} \mathrm{OCH}_{2} \mathrm{CH}\left(\mathrm{CO}_{2}\right) \mathrm{NH}_{2^{\circ}}+{ }^{\mathrm{Li}}\right]^{+}\right)^{\text {) }}$ (Figure $\left.5 \mathrm{a}\right)$, which is a lithiated ion of a lithium phosphoserine. Similar results were also observed in the product-ion spectrum of the $[\mathrm{M}-\mathrm{H}+2 \mathrm{Na}]^{+}$ion of 18:0/18:1-PS at $m / z 834$ (Figure $\left.{ }^{\circ} 5 f\right) .{ }^{\circ}$ The $^{\circ}$ above $^{\circ}$ results $^{\circ}$ are $^{\circ}$ consisten $^{\circ}$ with $^{\circ}$ the notion that cleavage of the $\mathrm{C} 3-\mathrm{OP}$ bond to form the alkali adduct ion of the alkali phosphoserine becomes more competitive than formation of the protonated ion of [M - alkali phosphoserine] moiety as $\mathrm{Li}^{+}$was replaced by $\mathrm{Na}^{+}$, similar to that observed for the $[\mathrm{M}+$ Alk] ${ }^{+}$ion. The competition between formation of the alkali adduct ion with polar head group and formation of the adduct ion with its complementary moiety becomes so strongly favorable to the former that ions deriving from consecutive fragmentation of the latter ion that leads to structural characterization are lost. This has been observed in the product-ion spectrum of the $[\mathrm{M}+\mathrm{Na}]^{+}$ion as seen earlier.

\section{The $[\mathrm{M}-2 \mathrm{H}+3 \mathrm{Alk}]^{+}$Ions}

In the presence of alkali metal ions, PS also forms [M $2 \mathrm{H}+3 \mathrm{Alk}]^{+}$ion by ESI because it contains two acidic 

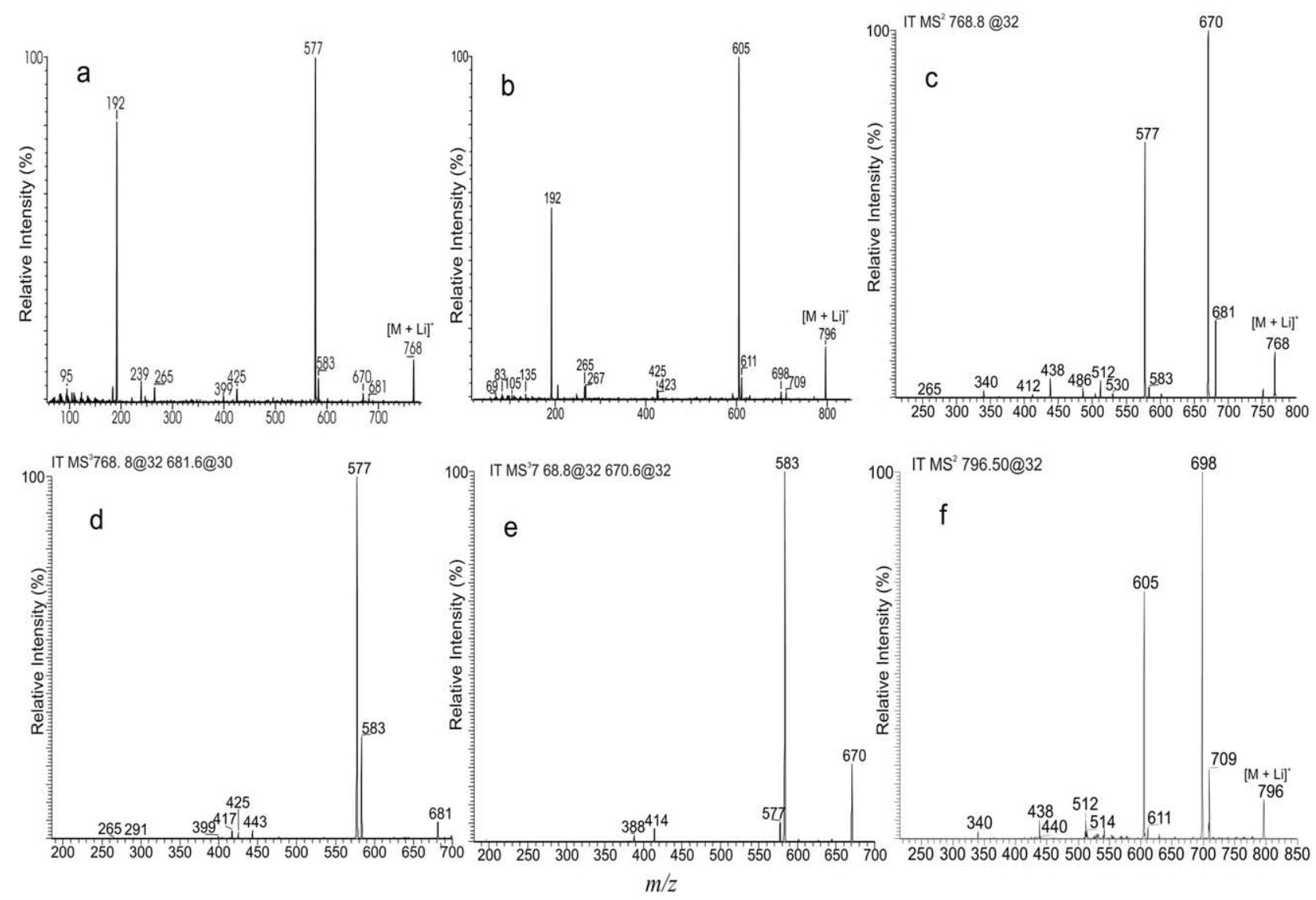

Figure 5. The product-ion spectra of the $[\mathrm{M}-\mathrm{H}+2 \mathrm{Li}]^{+}$ion of 16:0/18:1-PS at $m / z 774$ obtained with (a) a TSQ instrument and (b) an ITMS instrument. (c) The IT MS ${ }^{3}$-spectrum of the $\mathrm{m} / \mathrm{z} 687$ ion $(774 \rightarrow$ 687) arising from $\mathrm{m} / \mathrm{z} 774$. (d)-(f) The tandem quadrupole product-ion spectra of (d) the $[\mathrm{M}-\mathrm{H}+$ $2 \mathrm{Li}]^{+}$ion of 18:0/22:6-PS at $\mathrm{m} / \mathrm{z} 848,(\mathbf{e})$ the $[\mathrm{M}-\mathrm{H}+2 \mathrm{Na}]^{+}$ion of 16:0/18:1-PS at $\mathrm{m} / \mathrm{z} 806$, and (f) of the $[\mathrm{M}-\mathrm{H}+2 \mathrm{Na}]^{+}$ion of 18:0/18:1-PS at $m / z 834$.

protons that can be replaced by alkali metal ions to form an alkali adduct ion of a dialkali salt. Both the $\mathrm{MS}^{2}$ spectra of the $[\mathrm{M}-2 \mathrm{H}+3 \mathrm{Na}]^{+}$ion of 16:0/18:1-PS at $\mathrm{m} / \mathrm{z} 828^{\circ}$ obtained $^{\circ}$ with $^{\circ} \mathrm{a}^{\circ} \mathrm{TSQ}^{\circ}\left(\text { Figure }^{\circ} 6 \mathrm{a}\right)^{\circ}$ and $^{\circ}$ an $^{\circ}$ ITMS (Figure $6 \mathrm{~b}$ ) instrument ${ }^{\circ}$ are ${ }^{\circ}$ dominated ${ }^{\circ} y^{\circ} \mathrm{m} / \mathrm{z} 741^{\circ}\left(828^{\circ}-\right.$ 87 ), which is probably equivalent to a sodiated ion of a disodium 16:0/18:1-PA. The ion at $\mathrm{m} / \mathrm{z} 572$ (828 $\mathrm{R}_{1} \mathrm{CO}_{2} \mathrm{H}$ ) ${ }^{\circ}$ arising ${ }^{\circ}$ from $\%$ oss ${ }^{\circ}$ of 16 :0-fatty ${ }^{\circ}$ acid ${ }^{\circ}$ substituent at $s n-1$ is more abundant than $m / z 546\left(828-\mathrm{R}_{2} \mathrm{CO}_{2} \mathrm{H}\right)$ arising from loss of the 18:1-fatty acid at $s n-2$. This preferential loss of $\mathrm{R}_{1} \mathrm{CO}_{2} \mathrm{H}$ over loss of $\mathrm{R}_{2} \mathrm{CO}_{2} \mathrm{H}$ is similar to that observed for phosphatidylcholine (PC), attributable to the fact that the loss of $\mathrm{R}_{1} \mathrm{CO}_{2} \mathrm{H}$ probably requires the $\alpha$-hydrogen of the fatty acyl group at $s n-2$, which is more labile than those at $s n-1$ that participate in the elimination of $\mathrm{R}_{2} \mathrm{CO}_{2} \mathrm{H}^{\circ}$ [27].

Further loss of the 18:1- and of the 16:0-fatty acyl substituents as sodium salts from $\mathrm{m} / \mathrm{z} 741$ gives rise to ions at $\mathrm{m} / \mathrm{z} 437\left(741-\mathrm{R}_{2} \mathrm{CO}_{2} \mathrm{Na}\right)$ and 463 (741 $\mathrm{R}_{1} \mathrm{CO}_{2} \mathrm{Na}$ ), respectively. This fragmentation process is supported by the IT $\mathrm{MS}^{3}$-spectrum of $\mathrm{m} / \mathrm{z} 741(828 \rightarrow$ $741)^{\circ}$ (Figure $\left.{ }^{\circ} 6 \mathrm{c}\right){ }^{\circ}$ which $^{\circ}$ contains $^{\circ}$ major $^{\circ}$ fragment ${ }^{\circ}$ ions

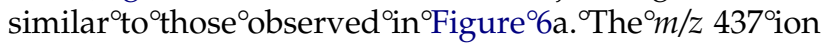

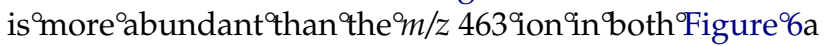

and c. This is consistent with the notion that loss of the fatty acyl substituents at $s n-2$ is more favorable than the similar loss at $s n-1$. However, ion at $\mathrm{m} / \mathrm{z} 485$ (741 $\mathrm{R}_{1} \mathrm{CO}_{2} \mathrm{H}$ ) arising from loss of the 16:0-fatty acyl substituent at $s n-1$ as an acid is more abundant than the $\mathrm{m} / \mathrm{z}$ 459 ion $\left(741-\mathrm{R}_{2} \mathrm{CO}_{2} \mathrm{H}\right)$, arising from loss of the $18: 1$-acid at $s n-2$. This is also in accord with the conception that loss of the 16:0-acid at sn-1 involves the more labile $\alpha$-hydrogens of the fatty acyl moiety at $s n-2$, while loss of the 18:1-acid involves the less labile $\alpha$-hydrogens of the fatty acyl moiety at $s n-1$ as described earlier. The observation of a greater abundance of the $\mathrm{m} / \mathrm{z} 477$ ion (741 $\left.-\mathrm{R}_{2}{ }_{2} \mathrm{CH}=\mathrm{CO}\right)$, arising from loss of the 18:1-fatty acyl ketene at $s n-2$, than the $\mathrm{m} / \mathrm{z} 503$ ion (741 $\mathrm{R}^{\prime}{ }_{1} \mathrm{CH}=\mathrm{CO}$ ), arising from loss of 16:0-fatty acyl ketene at $s n-1$ is also consistent with the assumption that the $\alpha$-hydrogens of the fatty acyl moiety at $s n-2$ are more labile than ${ }^{\circ}$ those ${ }^{\circ} a^{\circ} s n-1^{\circ}[27]$.

Ions reflecting the polar head group were observed at $m / z 252$, corresponding to a sodiated disodium salt of phosphoserine and at $\mathrm{m} / \mathrm{z} 165$, representing a sodiated disodium phosphate $\left(\left[\mathrm{Na}_{2} \mathrm{HPO}_{4}+\mathrm{Na}\right]^{+}\right)$. The observation of the differential losses of the fatty acyl substituents pertaining to their position on the glycerol back- 

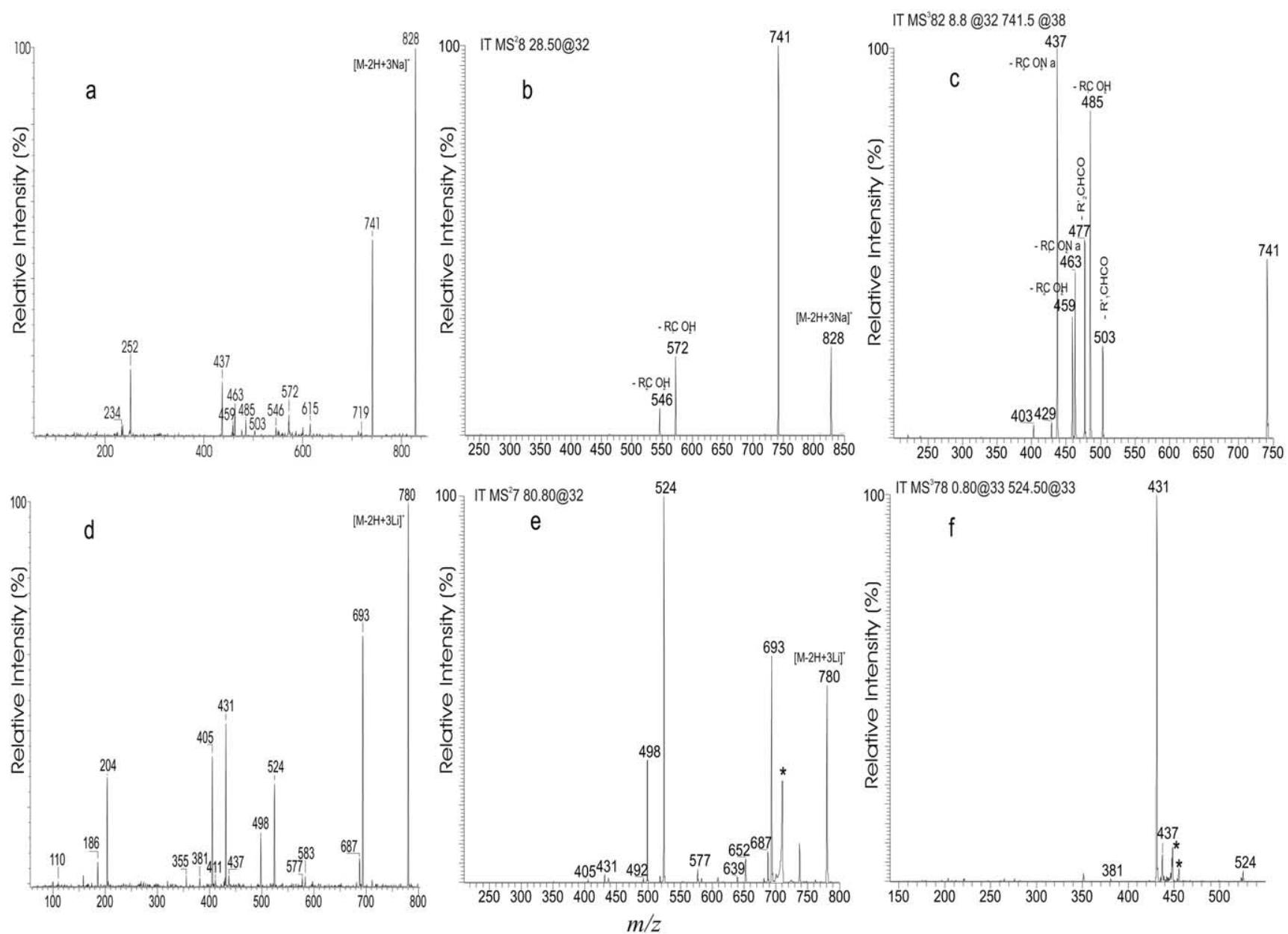

Figure 6. The product-ion spectra of the $[\mathrm{M}-2 \mathrm{H}+3 \mathrm{Na}]^{+}$ion of $16: 0 / 18: 1-\mathrm{PS}$ at $\mathrm{m} / \mathrm{z} 828$ obtained with (a) a TSQ instrument, (b) an ITMS instrument, and (c) its IT MS ${ }^{3}$-spectrum of the $\mathrm{m} / \mathrm{z} 741$ ion (828 $\rightarrow 741)$. (d)-(e) The product-ion spectra of the $[\mathrm{M}-2 \mathrm{H}+3 \mathrm{Li}]^{+}$ion of 16:0/18:1-PS at $\mathrm{m} / \mathrm{z} 780$ obtained with (d) a TSQ instrument, (e) an ITMS instrument, and (f) its IT MS ${ }^{3}$-spectrum of the $\mathrm{m} / \mathrm{z} 524$ ion (780 $\rightarrow 524)$.

bone, along with the presence of the ions representing the polar head group permits the structure of PS to be unambiguously unveiled.

The product-ion spectra of the $[\mathrm{M}-2 \mathrm{H}+3 \mathrm{Li}]^{+}$ion of 16:0/18:1-PS ${ }^{\circ}$ at ${ }^{\circ} \mathrm{m} / \mathrm{z} 780^{\circ}$ obtained $^{\circ}$ with $^{\circ} \mathrm{a}^{\circ} \mathrm{TSQ}^{\circ}$ (Figure ${ }^{\circ} 6 \mathrm{~d}$ ) and $^{\circ}$ an $^{\circ}$ ITMS $^{\circ}\left(\text { Figure }^{\circ} 6\right)^{\circ}{ }^{\circ}$ instrument ${ }^{\circ}$ Contain $^{\circ}$ ions ${ }^{\circ}$ analogous to those observed for the $[\mathrm{M}-2 \mathrm{H}+3 \mathrm{Na}]^{+}$ion (Figure ${ }^{\circ} 6 \mathrm{a}^{\circ}$ and $\left.^{\circ} \mathrm{b}\right) .^{\circ}$ However, ${ }^{\circ}$ the ${ }^{\circ}$ ion $^{\circ}$ at $^{\circ} \mathrm{m} / \mathrm{z} 431^{\circ}\left(693^{\circ}-\right.$ $\mathrm{C}_{15} \mathrm{H}_{31} \mathrm{CO}_{2} \mathrm{Li}$ ) arising from loss of the 16:0-fatty acyl substituent at $s n-1$ as a lithium salt from $\mathrm{m} / z 693$ becomes more abundant than $m / z 405\left(693-\mathrm{C}_{17} \mathrm{H}_{33} \mathrm{CO}_{2} \mathrm{Li}\right)$, arising from the analogous loss at $s n-2$. This reversal in the abundances of these two ions (compared with the $\mathrm{m} / \mathrm{z} 463$ and $^{\circ} 437^{\circ}$ ions $^{\circ}$ in ${ }^{\circ}$ Figure $\left.^{\circ} 6 a\right)^{\circ}$ is ${ }^{\circ}$ attributable ${ }^{\circ}$ to $^{\circ}$ the ${ }^{\circ}$ fact ${ }^{\circ}$ that both the $\mathrm{m} / \mathrm{z} 431$ and 405 ions arise mainly from $\mathrm{m} / \mathrm{z} 524$ and 498 , respectively, via further loss of the $\mathrm{C}_{3} \mathrm{H}_{5} \mathrm{NO}_{2}$ moiety as a lithium salt $(93 \mathrm{Da})$. These fragmentation pathways are supported by the $\mathrm{MS}^{3}$-spectra of $\mathrm{m} / \mathrm{z} 524$ $\left(780^{\circ} \rightarrow{ }^{\circ} 524\right)^{\circ}$ (Figure $^{\circ} 6 \mathrm{f}^{\circ}$ and $^{\circ} \mathrm{m} / \mathrm{z} 498^{\circ}\left(780^{\circ} \rightarrow^{\circ} 498\right)^{\circ}$ (not shown). Because the $m / z 524$ ion is preferentially formed over the $\mathrm{m} / \mathrm{z} 498$ ion in the primary fragmentation process, ion at $m / z 431(524-93)$ becomes more abundant than the $m / z 405$ (498 - 93) ion, resulting from consecutive dissociations. The $\mathrm{m} / \mathrm{z} 431$ and 405 ions can also arise from further decomposition of $m / z 687$, which is equivalent to a lithiated adduct ion of a monolithium salt of 16:0/18:1-PA and undergoes preferential loss of the 16:0-fatty acid to give $m / z 431$ over loss of the 18:1-fatty acid moiety to give $m / z 405$. This fragmentation process has been described for the $\left.{ }^{\circ} \mathrm{M}^{\circ}-{ }^{\circ} \mathrm{H}^{\circ}+2 \mathrm{Li}\right]^{+}{ }^{\circ}$ ion ${ }^{\circ}$ of ${ }^{\circ} 16: 0 / 18: 1-\mathrm{PS}^{\circ} \mathrm{t}^{\circ} \mathrm{m} / \mathrm{z} 74^{\circ}$ (Figure $5 a^{\circ}$ and $^{\circ} \mathrm{C}$ ). ${ }^{\circ}$ The ${ }^{\circ}$ consecutive ${ }^{\circ}$ fragmentation ${ }^{\circ}$ of ${ }^{\circ}$ the ${ }^{\circ} \mathrm{m} / z 693$ ion $(780 \rightarrow 693$ ) (not shown) also yields ions at $m / z 431$ and 405 but requires higher collision energy than do the $\mathrm{m} / \mathrm{z}$ 524 and 498 ions that yield the similar ions, and thus the pathway is less favorable. As a result, the $m / z 431$ ion is more prominent than $\mathrm{m} / \mathrm{z} 405$ in the product-ion spectrum observed for the $[\mathrm{M}-2 \mathrm{H}+3 \mathrm{Li}]^{+}$ion of 16:0/18:1-PS.

\section{Conclusions}

The tandem mass spectrometry of the various molecular ions of phosphatidylserine generated by ESI as described above represents the broad applicability of various molecular ions of phospholipids that can be 
exploited for structural characterization. The tandem mass spectrum of the $[\mathrm{M}-\mathrm{H}]^{-}$ion of PS contains complete structural information and offers the utmost sensitivity for structural determination. In contrast, product-ion spectra from the $[\mathrm{M}+\mathrm{H}]^{+}$species are rather simple and are less useful for structural characterization. The product-ion spectra arising from $[\mathrm{M}-2 \mathrm{H}+\mathrm{Alk}]^{-},[\mathrm{M}+\mathrm{Alk}]^{+},[\mathrm{M}-\mathrm{H}+$ $2 \mathrm{Alk}]^{+}$, and $[\mathrm{M}-2 \mathrm{H}+3 \mathrm{Alk}]^{+}($where Alk $=\mathrm{Li}, \mathrm{Na})$, on the other hand, contain multiple sets of fragment ions informative for identification of the polar head group, the fatty acyl substituents, and their positions on the glycerol backbone. The rearrangement process leading to internal loss of the phosphate moiety observed in the IT $\mathrm{MS}^{2}$-spectra of the $[\mathrm{M}+\mathrm{Alk}]^{+}$ions of PS is unique. Another interesting note from this study is that the IT $\mathrm{MS}^{2}$-spectrum of the $[\mathrm{M}-2 \mathrm{H}+$ $3 \mathrm{Li}]^{+}{ }^{\circ}$ ion $^{\circ}$ at $^{\circ} \mathrm{m} / z \quad 780^{\circ}\left(\text { Figure }^{\circ} 6 \mathrm{c}\right)^{\circ}$ along $^{\circ}$ with $^{\circ}$ its $^{\circ}$ IT $\mathrm{MS}^{3^{\circ}}$-spectra ${ }^{\circ}$ of ${ }^{\circ}$ the $\mathrm{o} / \mathrm{z} / 524^{\circ}\left(780^{\circ} \rightarrow{ }^{\circ} 524,{ }^{\circ}\right.$ Figure $\left.{ }^{\circ} 6 \mathrm{f}\right){ }^{\circ}$ and $m / z 693$ ions $(780 \rightarrow 693$, not shown), as well as the IT $\mathrm{MS}^{3^{\circ}}$-spectrum ${ }^{\circ}$ of $^{\circ}$ the ${ }^{\circ} \mathrm{m} / z$ 687 ${ }^{\circ}$ ion $^{\circ}\left(774^{\circ} \rightarrow^{\circ} 687\right.$, ${ }^{\circ}$ Figure $5 \mathrm{c})^{\circ}$ from $^{\circ}$ the ${ }^{\circ}\left[\mathrm{M}^{\circ}-{ }^{\circ} \mathrm{H}^{\circ}+{ }^{\circ} 2 \mathrm{Li}\right]^{+}{ }^{\circ}$ ion $^{\circ}$ at ${ }^{\circ} \mathrm{m} / \mathrm{z} 774^{\circ}$ also contain several ions that are broad and asymmetric (marked ${ }^{\circ}$ with $^{\circ}$ an $^{\circ}$ asterisk). ${ }^{\circ}{ }^{\circ}{ }^{\circ}$ contrast, ${ }^{\circ}$ the ${ }^{\circ}$ analogous ions are not present in the spectra arising from the corresponding ${ }^{\circ}\left[\mathrm{M}^{\circ}-{ }^{\circ} 2 \mathrm{H}^{\circ}+{ }^{\circ} 3^{\circ} \mathrm{Na}\right]^{+}{ }^{\circ}$ (Figure ${ }^{\circ} 6 \mathrm{~b}^{\circ}$ and $^{\circ} \mathrm{C}$ ) and $[\mathrm{M}-\mathrm{H}+2 \mathrm{Na}]^{+}(806 \rightarrow 719$, not shown) species. Asymmetric peaks resulting from peak fronting observed by ITMS have been previously reported and were thought to arise from "fragile" precursors during application of resonance ejection in mass analysis $\left[30,{ }^{\circ} 31\right] .^{\circ}$ The $^{\circ}$ mechanisms $^{\circ}$ leading $^{\circ}$ to $^{\circ}$ the $^{\circ}$ rearrangement process as well as to the formation of the asymmetric ions as observed in this study are currently under investigation.

\section{Acknowledgments}

This research was supported by U.S. Public Health Service grants P41-RR-00,954， R37-DK-34,388, P60-DK-20,579, P01-HL-57,278, P30-DK-56,341, and a grant (996003) from the Juvenile Diabetes Foundation. The authors thank the reviewers for their critical comments on this manuscript.

\section{References}

1. Folch, J. The chemical structure of phosphatidylserine. J. Biol. Chem. 1948,17, 439-450.

2. Baer, E.; Maurukas, J. Phosphatidylserine. J. Biol. Chem. 1955, 212, 25-38.

3. Baer, E.; Maurukas, J. The diazometholysis of glycerolphosphatides: A novel method of determining the configuration of phosphatidylserines and cephalins. J. Biol. Chem. 1955, 212, $39-48$.

4. Kanfer, J.; Kennedy, E. P. Metabolism and function of bacterial lipids: II. Biosynthesis of phospholipids in Escherichia coli. J. Biol. Chem. 1964, 239, 1720-1726.

5. Hübscher, H. G.; Dils, R. R.; Pover, W. F. R. Studies on the biosynthesis of phosphatidylserine. Biochim. Biophys. Acta 1959, 36, 518-528.
6. Dennis, E. A.; Kennedy, E. P. Enzymatic synthesis and decarboxylation of phosphatidylserine in Tetrahymena pyriformis. J. Lipid Res. 1970, 11, 394-403.

7. Bittova, L.; Stahelin, R. V.; Cho, W. Roles of ionic residues of the $\mathrm{C} 1$ domain in protein kinase $\mathrm{C}$-A activation and the origin of phosphatidylserine specificity. J. Biol. Chem. 2001, 276, $4218-4226$.

8. Stekhoven, F. M.; Tijmes, J.; Umeda, M.; Inoue, K.; De Pont, J. J. Monoclonal antibody to phosphatidylserine inhibits $\mathrm{Na}+$ / K(+)-ATPase activity. Biochim. Biophys. Acta 1994, 1194, 155165.

9. Hofmann, K.; Tomiuk, S.; Wolff, G.; Stoffel, W. Cloning and characterization of the mammalian brain-specific, $\mathrm{Mg}^{2+}$-dependent neutral sphingomyelinase. Proc. Natl. Acad. Sci. U.S.A. 2000, 97, 5895-5900.

10. Tamiya-Koizumi, K.; Kojima, K. Activation of magnesiumdependent, neutral sphingomyelinase by phosphatidylserine. J. Biochem. (Tokyo) 1986, 99, 1803-1806.

11. Bevers, E.; Comfurius, P.; van Rijn, J.; Hemker, H.; Zwaal, R. Generation of prothrombin-converting activity and the exposure of phosphatidylserine at the outer surface of platelets. Eur. J. Biochem. 1982, 122, 429-436.

12. van den Eijnde, S. M.; van den Hoff, M. J. B.; Reutelingsperger, C. P. M.; van Heerde, W. L.; Henfling, M. E. R.; Vermeij-Keers, C.; Schutte, B.; Borgers, M.; Ramaekers, F. C. S. Transient expression of phosphatidylserine at cell-cell contact areas is required for myotube formation. J. Cell Sci. 2001, 114, 36313642.

13. Fadok, V. A.; Voelker, D. R.; Campbell, P. A.; Cohen, J. J.; Bratton, D. L.; Henson, P. M. Exposure of phosphatidylserine on the surface of apoptotic lymphocytes triggers specific recognition and removal by macrophages. J. Immunol. 1992, 148, 2207-2216.

14. Fadok, V. A.; de Cathelineau, A.; Daleke, D. L.; Henson, P. M.; Bratton, D. L. Loss of phospholipid asymmetry and surface exposure of phosphatidylserine is required for phagocytosis of apoptotic cells by macrophages and fibroblasts. J. Biol. Chem. 2001, 276, 1071-1077.

15. Bennett, M. R.; Gibson, D. F.; Schwartz, S. M.; Tait, J. F. Binding and phagocytosis of apoptotic vascular smooth muscle cells is mediated in part by exposure of phosphatidylserine. Circ. Res. 1995, 77, 1136-1142.

16. Martin, S. J.; Reutelingsperger, C. P.; McGahon, A. J.; Rader, J. A.; van Schie, R. C.; LaFace, D. M.; Green, D. R. Early redistribution of plasma membrane phosphatidylserine is a general feature of apoptosis regardless of the initiating stimulus: Inhibition by overexpression of Bcl-2 and Abl. J. Exp. Med. 1995, 182, 1545-1556.

17. Schlegel, R. A.; Callahan, M. K.; Williamson, P. The central role of phosphatidylserine in the phagocytosis of apoptotic thymocytes. Annals N.Y. Acad. Sci. 2000, 926, 217-225.

18. Tyurina, Y. Y.; Shvedova, A. A.; Kawai, K.; Tyurin, V. A.; Kommineni, C.; Quinn, P. J.; Schor, N. F.; Fabisiak, J. P.; Kagan, V. E. Phospholipid signaling in apoptosis: Peroxidation and externalization of phosphatidylserine. Toxicology 2000, $148(2 / 3), 93-101$.

19. Li, M. O.; Sarkisian, M. R.; Mehal, M. Z.; Rakic, P.; Flavell, R. A. Phosphatidylserine receptor is required for clearance of apoptotic cells. Science 2003, 302 (5650), 1560-1563.

20. Chen, S.; Kirschner, G.; Traldi, P. Positive ion fast atom bombardment mass spectrometric analysis of the molecular species of glycerophosphatidylserine. Anal. Biochem. 1990, 191, 100-105.

21. Murphy, R. C.; Harrison, K. A. Fast atom bombardment mass spectrometry of phospholipids. Mass Spectrom. Rev. 1994, 13, $57-75$. 
22. Ho, Y. P.; Huang, P. C.; Deng, K. H. Metal ion complexes in the structural analysis of phospholipids by electrospray ionization tandem mass spectrometry. Rapid Commun. Mass Spectrom. 2003, 17, 114-21.

23. Pulfer, M.; Murphy, R. C. Electrospray mass spectrometry of phospholipids. Mass Spectrom. Rev. 2003, 22, 332-364.

24. Hsu, F.-F.; Turk, J. Charge-driven fragmentation processes in diacyl glycerophosphatidic acids upon low-energy collisional activation. A mechanistic proposal. J. Am. Soc. Mass Spectrom. 2000, 11, 797-803.

25. Hsu, F-F.; Turk, J. Charge-driven and charge-remote fragmentation processes in diacyl glycerophosphoethanolamine upon low-energy collisional activation. A mechanistic proposal. J. Am. Soc. Mass Spectrom. 2000, 11, 892-899.

26. Hsu, F.-F.; Turk, J. Characterization of phosphatidylethanolamine as a lithiated adduct by triple quadrupole tandem mass spectrometry with electrospray ionization. J. Mass. Spectrom. 2000, 35, 595-606.

27. Hsu, F.-F.; Turk, J. Electrospray ionization/tandem quadrupole mass spectrometric studies on phosphatidylcholines:
The fragmentation processes. J. Am. Soc. Mass Spectrom. 2003, 14, 352-363.

28. Hsu, F.-F.; Turk, J. Structural characterization of triacylglycerols as lithiated adducts by electrospray ionization mass spectrometry using low-energy collisionally activated dissociation on a triple stage quadrupole instrument. J. Am. Soc. Mass Spectrom. 1999, 10, 587-599.

29. Hsu, F.-F.; Bohrer A.; Turk, J. Formation of lithiated adducts of glycerophosphocholine lipids facilitates their identification by electrospray ionization tandem mass spectrometry. J. Am. Soc. Mass Spectrom. 1998, 9, 516-526.

30. McClellan, J. E.; Murphy, J. P., III; Mulholland, J. J.; Yost, R. A. Effect of fragile ions on mass resolution and on isolation for tandem mass spectrometry in the quadrupole ion trap mass spectrometer. Anal. Chem. 2002, 74, $402-412$.

31. Murphy, J. P., III; Yost, R. A. Origin of mass shifts in the quadrupole ion trap: Dissociation of fragile ions observed with a hybrid ion trap/mass filter instrument. Rapid Commun. Mass Spectrom. 2000, 14, 270-273. 